University of Louisville

ThinkIR: The University of Louisville's Institutional Repository

Electronic Theses and Dissertations

$5-2021$

\title{
"The only prize worth contending for": a history of Eckstein Norton University and the industrial model of education in Kentucky.
}

Samuel Dunn

University of Louisville

Follow this and additional works at: https://ir.library.louisville.edu/etd

Part of the Cultural History Commons

\section{Recommended Citation}

Dunn, Samuel, "'The only prize worth contending for": a history of Eckstein Norton University and the industrial model of education in Kentucky." (2021). Electronic Theses and Dissertations. Paper 3614. https://doi.org/10.18297/etd/3614

This Master's Thesis is brought to you for free and open access by ThinkIR: The University of Louisville's Institutional Repository. It has been accepted for inclusion in Electronic Theses and Dissertations by an authorized administrator of ThinkIR: The University of Louisville's Institutional Repository. This title appears here courtesy of the author, who has retained all other copyrights. For more information, please contact thinkir@louisville.edu. 
“THE ONLY PRIZE WORTH CONTENDING FOR":

A HISTORY OF ECKSTEIN NORTON UNIVERSITY

AND THE INDUSTRIAL MODEL OF EDUCATION IN KENTUCKY

By

Samuel Dunn

B.A., University of Louisville, 2019

A Thesis Submitted to the

Faculty of the College of Arts and Sciences

of the University of Louisville in Partial Fulfillment of the Requirements for the Degree of

Master of Arts in History

Department of History

University of Louisville

Louisville, Kentucky

May 2021 

“THE ONLY PRIZE WORTH CONTENDING FOR”:

A HISTORY OF ECKSTEIN NORTON UNIVERSITY

AND THE INDUSTRIAL MODEL OF EDUCATION IN KENTUCKY

By

Samuel Dunn

A Thesis Approved on

$4 / 16 / 2021$

By the following Thesis Committee

Thesis Chair (Dr. Albert Glenn Crothers)

Committee Member (Dr. Tracy E. K'Meyer)

Committee Member (Dr. Sherri L. Wallace) 


\section{ACKNOWLEDGMENTS}

I would like to thank my advisor, Dr. Glenn Crothers, whose advice and mentorship has been indispensable throughout the research and writing process. I would also like to thank Dr. Tracy K'Meyer and Dr. Sherri Wallace, both of whom offered valuable guidance. Their influence can be found throughout this thesis.

Thank you to the Norton family, who first brought this subject to my attention. They demonstrated remarkable helpfulness and enthusiasm. Thank you to the Bullitt County Historical Society, particularly Daniel Buxton. They are a wonderful group of people and guided me towards a wealth of research materials.

Thank you to everyone in the History Department of the University of Louisville. I am continually inspired by the depth of your knowledge and your passion for history.

Thank you to my friends and family, whose constant interest and encouragement drove me to the finish line. Special thanks to my friends who listened patiently while I described the smallest details of my research and writing process. My hope is that your good-natured suffering served a good cause.

I dedicate this thesis to Tom and April Dunn, my loving and supporting parents, who first got me interested in history. You continue to be awesome. 


\section{ABSTRACT \\ “THE ONLY PRIZE WORTH CONTENDING FOR”: \\ A HISTORY OF ECKSTEIN NORTON UNIVERSITY \\ AND THE INDUSTRIAL MODEL OF EDUCATION IN KENTUCKY}

Samuel Dunn

April 16, 2021

Under the racial hierarchy of Jim Crow, white politicians in Kentucky limited African American access to higher education. This practice resulted in a shortage of African American teachers and severely inhibited Black education across the state. Despite frequent criticism of the industrial model of education, African American educators in the region viewed the approach as an opportunity to gain white support for Black education. Two prominent educators, William J. Simmons and C.H. Parrish, gained the support of white elites and opened Eckstein Norton University in 1890. Their close association with prominent whites provided a degree of anonymity, enabling them to offer instruction in both industrial and traditional liberal arts subjects. In the face of personal tragedy, financial instability, and institutionalized discrimination, Eckstein Norton University educated many African Americans and improved the educational opportunities available to Black Kentuckians. 
TABLE OF CONTENTS

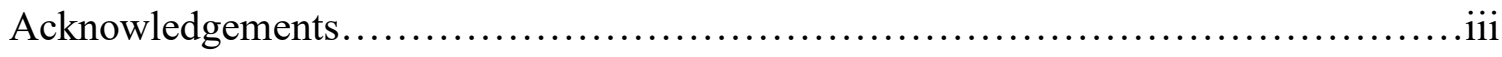

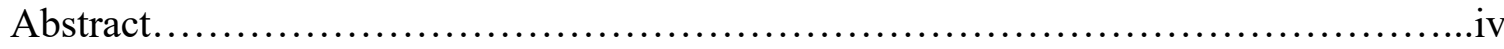

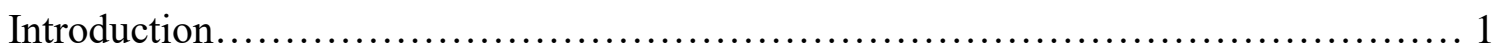

Chapter 1: Flawed Opportunities: Industrial Education in Jim Crow Kentucky .......... 29

Chapter 2: A "Feasible and Practical" Plan: Two Educators Begin Their Journey........ 54

Chapter 3: "Ruining Good Plow Hands": The Work of Eckstein Norton University..... 74

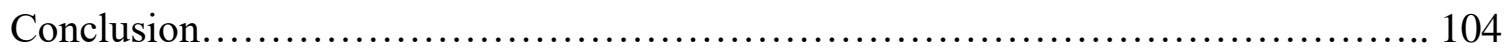

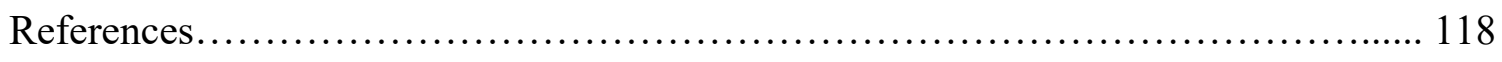

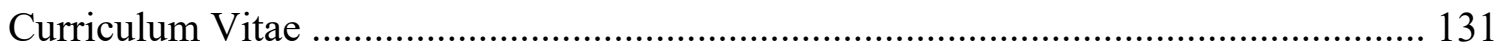




\section{INTRODUCTION}

On January 24, 1892, the main building of Eckstein Norton University, which housed forty-eight African American women, caught fire. The students and faculty of the school had just begun their Sunday morning church services when the alarm rang out, prompting the worshippers to leave the small chapel and fight the blaze. Despite their efforts, the fire quickly consumed the roof of the building. The disaster destroyed school records, educational materials, and the belongings of the forty-eight students. Thankfully, no students or faculty members died, but the flames devastated the small university and left the school in desperate need of financial assistance. ${ }^{1}$ Coming just two years after the founding of the school, the fire was a setback. While it did not stop the leaders of the institution from seeking to educate African Americans in Kentucky as best they could, the fight against the blaze seemed an apt metaphor for the struggle of the school to survive and accomplish its goals in the sometimes inhospitable climate of the Commonwealth.

The very nature of the school and its curriculum became a tactic for obtaining educational equality. In the post-Civil War era, racial violence and the white-dominated state legislature limited Black post-secondary educational opportunities. Whites feared that any Black educational efforts, especially those with a traditional liberal arts curriculum, would challenge white supremacy, which was a series of laws and socioeconomic practices supporting the racial hierarchy known in this period as Jim Crow. 
Whites intended to maintain their supremacy by restricting access to education, just as they had enforced it through discrimination and racist employment practices. But African Americans in Kentucky and elsewhere around the South were determined to expand their educational opportunities. To do so, they embraced the industrial model of education.

In the late nineteenth and early twentieth centuries, the industrial model, which offered education to African American students but focused on vocational training, represented a compromise between whites and Blacks. White business owners, concerned that their labor force might move to the North or become so uneducated as to be useless in a modernizing economy, viewed industrial education as means to train African Americans to be productive laborers while protecting white social and economic superiority. But they conceded to African American demands for post-secondary education. Thus, as long as Black educators avoided traditional liberal arts subjects, at least publicly, African American industrial schools gained the financial and political support of whites who believed it diminished the possibility of racial unrest.

Within the African American community, the use of the industrial approach prompted debate, eventually becoming associated with two prominent African American leaders; Booker T. Washington and W. E. B Du Bois. Washington, the face of the industrial model, embraced accommodation. He believed that economic participation, not social protest, would eventually lead to racial equality. From his perspective, the industrial model, which prepared African Americans to engage in the white southern economy, offered the best path toward racial uplift. Du Bois, once an admirer of Washington, came to hold a much different view. Du Bois both advocated for African 
American access to liberal arts higher education and supported organized protest. Washington viewed Du Bois's displays of militancy as counterproductive to his gradual approach to equality, while DuBois accused supporters of the industrial model of allowing "a new slavery to rise." 2 The battle between Washington and Du Bois mirrored the discussions within African American communities across the South. All agreed with the goal of equality, but little consensus existed on the best way to attain it.

Although the Washington-DuBois debate ignited passions across the South, it did not determine the behavior of local and regional educators. These men and women "on the ground" were aware of the broader debate, but their actions remained rooted in the realities of Black education in the Jim Crow South. Facing persistent white resistance to African American education, particularly higher education, educators and administrators embraced whichever educational model offered the best chance of success. Many African Americans, facing a choice between no or limited education, utilized the industrial model. Some Black educators, ostensibly overseeing industrial schools, challenged white supremacy by covertly teaching their students traditional liberal arts subjects. Even when industrial schools strictly followed the industrial model, they still enlarged African American educational opportunities in an otherwise bleak environment. Consequently, many African Americans in the South worked with elite whites to spread industrial education across the region. They did so not because they wanted to maintain or accommodate white supremacy, but because the industrial model promised some degree of economic and educational development for Black southerners. 
In the face of economic, social, and political oppression, many hopeful African Americans viewed industrial education as an advancement in Black education. This thesis argues that William Simmons and C.H. Parrish, two African American educators in Kentucky, employed the industrial model as a means to gain white support of Black higher education. White approval of the industrial model allowed their school to function independently of white control and created an opportunity for the teaching of a liberal arts curriculum. Although the successful operation of the school necessitated regular white financial support, their goal remained the improvement of African American educational prospects across the state. The two men and their associates committed themselves to this purpose, although they faced discrimination and the specter of racial violence.

The faculty and students of Eckstein Norton University had the support of prominent white businessmen in nearby Louisville, Kentucky, but they had to wonder if the fire was an accident or a deliberate act by whites who opposed African American education. School leaders assuredly asked themselves if this was an act of racial violence and if nearby whites, previously helpful, had now turned against the school. Such questions represented just some of the concerns of southern African American educators in the decades after Reconstruction ended in 1877. African Americans faced real challenges in the region, and discrimination and the regular threat and reality of racial violence circumscribed Black lives and opportunities. Understanding the story of Eckstein Norton University and why the institution's faculty and students feared the possibility of racial violence, requires a review of the experience of Black southerners, 
and the ways in which historians have interpreted their narratives after the Civil War and emancipation.

\section{HISTORIOGRAPHY}

The United States Civil War and Reconstruction era has generated extensive interest among scholars and popular audiences. Many works of art, scholarly and popular books, and films have explored the Civil War, seeking to describe the causes, course, and consequences of the conflict. These efforts have shaped how the Civil War is taught in schools, influencing how future generations remember the war and its ramifications. The effort to construct a cohesive public memory of the war has also generated many divisions. By World War I, many historians and most white Americans subscribed to some version of the Lost Cause or Reconciliationist mythologies. First formulated by former Confederates and southern historians in the immediate aftermath of the war, the Lost Cause narrative helped to restore southern pride after the Confederate defeat in the war. The mythology emphasized several key points of southern propaganda. It depicted slavery as a benevolent institution and claimed that emancipation harmed both whites and African Americans. It also stressed the barbarity of the Union military, the infallibility of southern leadership, and viewed federal Reconstruction as an act of criminality meant to exploit southern whites. The promoters of the Lost Cause narrative promoted it in a variety of ways, including the building of southern monuments that became physical representations of southern historical revisionism. ${ }^{3}$

The inherently one-dimensional Lost Cause narrative ignored both the mistakes of the Confederate leadership and the struggles and achievements of African Americans who lived in the South. In fact, the narrative completely disregarded the African 
American experience except to accentuate negative Black stereotypes and tout the benefits of white paternalism. By the early twentieth century, the myth of the Lost Cause, reinforced through popular writings and films such as The Birth of a Nation, had become cemented in popular memory and the narratives written by white historians. The Lost Cause promoters simplified the history of the Civil War, Reconstruction, and postReconstruction eras, creating a narrative that disregarded the voices of already marginalized African Americans and falsified the historical record in the effort to prioritize and glorify the experiences of white southerners. The Lost Cause narrative removed African Americans from the narrative of the Civil War, making it easier for white southerners to discriminate against and target African Americans and for white northerners to ignore racial issues. Sadly, the myth of the Lost Cause narrative still influences the popular memory of many white Americans today.

In the past fifty years, historians have refuted key tenets of the Lost Cause mythology and highlighted the complexity of the Civil War-era South. Historians no longer view slavery as a beneficial institution or emancipation as a harmful development for African Americans. Instead, scholars recognize that emancipation offered great hope for African Americans who sought social and economic equality in the South and the nation. Emancipation failed to achieve this end because white southerners used violence and intimidation to subjugate the freed people and white northerners, tired of the military occupation of the South, sought sectional reconciliation.

Scholars also recognize that African Americans developed their own narratives of the Civil War and its meanings that differed from the popular narratives embraced by 
many whites. Most notably, historian David Blight has described the competing public memories of the war. He asserts that although the Lost Cause narrative ultimately assumed a prominent place in how white Americans remembered the war, it was challenged by both the "Emancipationist" view embraced by African Americans and their white allies and the "Reconciliationist" view popular among white Americans who sought national unity in the postwar years. Blight portrays the struggle over the public memory of the Civil War as a contest that pitted the romanticism of the Lost Cause and Reconciliation narratives against the realism and inclusion of the Emancipationist narrative. The Emancipationist memory of the war, embraced by African American leaders such as Frederick Douglass and Radical Republicans in Congress, viewed slavery as the precipitating factor of the conflict and emancipation as its most significant result. The Emancipationist view accurately portrayed slavery as a violent and exploitative institution and called for the full political and civil equality of Black Americans. This narrative, with its rejection of white supremacy and its intrinsic focus on the experiences of African Americans, diverging sharply from the Lost Cause and Reconciliationist ideologies. $^{4}$

The white supremacist approach to public memory developed quickly after the war, as white southerners struggled to maintain control over politics and African Americans. Terrorist groups such as the Ku Klux Klan spread across the former Confederacy, intimidating and attacking African Americans and white Republican politicians. African Americans who achieved economic prosperity despite white repression also faced the wrath of white supremacist groups. Even poor Black southerners who avoided political involvement encountered regular threats, the potential 
victims of the mob violence that whites used to enforce their control. In short, southern whites made it clear that they would resort to violence to preserve the racial status quo. ${ }^{5}$ Blight also notes that proponents of white supremacy spread their ideology in other, less violent ways. They portrayed slavery as a beneficial institution and African Americans as intellectually inferior or prone to criminal activities. By spreading these racial stereotypes, white leaders rationalized their efforts to disenfranchise and segregate African Americans. Their racialized narrative also validated discrimination, racial violence, and efforts to marginalize African American memories of the war. ${ }^{6}$

The Reconciliationist memory of the Civil War, according to Blight, also rejected the Emancipationist view. Reconciliationists like newspaper editor and Liberal Republican Horace Greeley chose to ignore the history of slavery and the role of African Americans in the Civil War. Instead, Reconciliationists highlighted the personal sacrifices of soldiers on both sides. Northern and southern whites resolved their differences by focusing on largely invented notions of martial glory and soldierly martyrdom. ${ }^{7}$ White Americans who embraced the myth of the fallen soldier ignored the deteriorating treatment of African Americans, remaining more concerned with establishing sectional goodwill and white unity. Most important, the Reconciliationist narrative shared many of the same emphases as the Lost Cause, enabling the latter to dominate the public memory of the war. In the process, it solidified and sustained the doctrines of white supremacy that lay at the heart of the Lost Cause narrative. White Americans who embraced the Reconciliationist memory ignored the marginalized voices and complex history of African Americans in the South and the nation. 
Since the 1960s and 70s, historians of the South have explored the centrality of slavery and discrimination in the region and highlighted those narratives that have gone unexamined to understand southern history in all of its complexity. Scholars dedicated to the study of the African American experience and agency have demonstrated that African Americans and other subjugated peoples did not submit meekly to the rule of the white elites, but instead resisted persecution and sought political, social, and economic equality, particularly after the Civil War. Recently scholarly work demonstrates that African American history and patterns of resistance were interlocked with the economic, political, and social history of the South. In short, any holistic history of the South must include the experiences of African Americans. This thesis seeks to contribute to this history by examining the use of the industrial model by Black Kentuckians at Eckstein Norton University as a means to gain white support for, and to improve, African American education.

\section{HISTORICAL CONTEXT}

The Civil War devastated the South's infrastructure and economy. The war destroyed the regions traditional plantation economy, based upon the labor of the enslaved. Millions of dollars invested in human bodies, the primary asset of southern elites, disappeared with emancipation. The northern and European textile market, long dependent upon southern cotton, found new sources of supply. Northern armies destroyed the South's railroad system, farms, and food reserves. The desperate efforts of the Confederate war machine to conscript food and other valuables depleted southern resources further. All told, four years of war left the region in desperate need of rehabilitation. 
Northern businessmen recognized the economic opportunities available in the devastated South and began to invest heavily in the region. Northern investors funded the development and improvement of railroads, which sparked the growth of urban centers where the railroads converged and terminated. ${ }^{8}$ The influence of the railroad companies and the growing southern dependence on rail travel also resulted in the formalization of time keeping and the division of the country into four time zones. ${ }^{9}$ Southern economic life, before the war predominately rural and agricultural, became more urban, commercialized, and industrialized and its working population more geographically mobile. Machine made goods permeated the southern market, as railroads facilitated trade and transportation. ${ }^{10}$ Northern investment sparked southern economic growth.

Yet postwar economic development did not always benefit southerners. Northern businessmen ensured that most of the profits generated by the new industry and commerce headed north, where the first large-scale corporations developed. Northern businessmen amassed great fortunes and gained control of entire industries. John D. Rockefeller created Standard Oil and controlled access to most of the oil produced in the United States. ${ }^{11}$ Andrew Carnegie founded the Carnegie Steel Company to respond to the growing demand for steel and became one of the wealthiest men in the country. ${ }^{12}$ Banker and financier J.P. Morgan led a financial revolution that centralized the American economy. ${ }^{13}$ Entrepreneurs like Rockefeller, Carnegie, and Morgan demonstrated both business acumen and growing generosity with the fortunes they acquired. Rockefeller once said of his philanthropic actions, "I believe that the power to make money is a gift of God. . . I believe it is my duty to make money and still more money and to use the money I make for the good of my fellow man."14 
But Rockefeller, Carnegie, and Morgan represented only a small portion of the economic capabilities of the late nineteenth century. Many successful northern businessmen, from a variety of industries, invested in the South. Many of them achieved considerable success through their southern investments, enabling them to expand their interests in the region. These businessmen also engaged in philanthropic activities, endowing schools, churches, and libraries across the South. Indeed, donating to a worthy cause became fashionable and socially expected among wealthy northern capitalists. The Rosenwald school building program represented one well-known example of this northern philanthropy. Sponsored by wealthy northerner Julius Rosenwald, the program helped to finance the creation of African American schools across the South. ${ }^{15}$ In the decades after the Civil War, northern philanthropy had a significant impact on southern cultural life, particularly in the development of educational institutions.

African Americans played a unique and vital role in the postwar southern economy. They constituted the most significant labor force in the region, in part because of the shortage of working age white men, many of whom had been killed or injured in the war. Additionally, employers paid African American laborers significantly lower wages than their white counterparts, making them an attractive workforce for both business and land owners. ${ }^{16}$ White employers, moreover, employed coercive methods to control African American labor and mobility. Through a variety of means, white landowners compelled African Americans to remain on the land owned by their former masters, receiving only a "share" of the crops they produced. Most important, white landowners charged Black sharecroppers exorbitant rates for food and rent, placing many in debt, and effectively tying them to the land. The poor state of the roads and dilapidated 
railroad system of the postwar South made it harder for African American laborers to migrate, further strengthening landowners' control. ${ }^{17}$

Some of the newly freed peoples purchased land, or rented it on favorable terms, but African Americans still faced discrimination from financial institutions and local merchants. Many white financial establishments would not lend to African Americans, or charged them above market interest rates, depriving Black southerners of the capital they needed to purchase land. General stores practiced similar forms of discrimination, often pushing African Americans to buy items on credit. In short order, many African American farmers fell into debt and sold their land to banks or local businessmen. ${ }^{18}$ Once the banks repossessed the property, they required struggling African American farmers to pay rent to work the land that they had previously owned, further deepening the cycle of debt. This predatory banking system, known as the crop-lien system, effectively prevented southern African American and many poor white families from creating generational wealth. ${ }^{19}$

Increasing northern investment in the South expanded the region's rail system, increased trade, and transformed African American employment opportunities. In the 1870's and 1880's, African American workers became even more important as the southern economy diversified, and employers and landowners scrambled to secure adequate labor. In rural areas, landowners and businessmen expanded the cycle of debt in their efforts to tie African Americans to the land. In the South's developing urban areas, employers worked to maintain and expand their labor force by offering competitive wages. ${ }^{20}$ Southern legislatures aided white employers' efforts to control African 
American labor by passing vagrancy laws that targeted African Americans who lacked the patronage of a white employer. ${ }^{21}$ African Americans living in urban areas experienced comparatively better conditions than those in rural areas, but they still worked for discriminatory wages and usually resided in slum-like housing in which disease and deprivation flourished. By the 1880's, both rural and urban African Americans, recognizing the untenable conditions of southern employment, began to migrate westward and northward in search of more equitable employment. ${ }^{22}$

Both northern investors and elite southern whites depended on inexpensive African American labor and thus sought ways to convince Black people to remain in the region. Recognizing the poor conditions of African American life, if not their own culpability in causing them, businessmen made efforts to improve African American living conditions and elite white philanthropy began to play a larger role in southern African American life, particularly in the development of schools. However, the schools that prominent whites patronized did not promote a traditional liberal arts curriculum. Instead, the schools' promoters touted industrial education, utilizing a curriculum that they believed would prepare African American students for a life of labor in the South. ${ }^{23}$ Nonetheless, many southern whites objected to the notion of Black education, even when funded by white philanthropists. African American education remained a prominent topic of debate, an issue made increasingly complex by the shifting political landscape of the post-war South.

The Republican Party - the party of Lincoln, emancipation, and Civil War victory - dominated national politics during and after the war. In the wake of Lincoln's April 
1865 assassination, Radical Republicans, who initially favored emancipation and later advocated for harsh post war measures, dominated the U.S. Congress. After successfully halting President Andrew Johnson's lenient Reconstruction policies toward former Confederates, the Republicans used their congressional majority to shepherd in widespread reform. ${ }^{24}$ Most important, Radical Republicans passed the Fourteenth Amendment to the Constitution, designed to ensure equal rights and protection under the law for the newly freed African Americans, and required that former Confederate states ratify the amendment before their readmission to the Union. Republicans also established the Freedman's Bureau, created to protect and empower African Americans as the South transitioned from a forced to free labor economy. After southern whites tried to suppress African American political access through violence in the immediate postwar years, Congress tasked the U.S. Army with ensuring that southern whites did not infringe upon the rights of African Americans. To facilitate military intervention, Congress divided the South into military districts and disbanded southern state legislatures until legislators wrote new constitutions that accepted African American political rights and held free and fair elections..$^{25}$

Military Reconstruction ended much of the racial violence and intimidation perpetrated by white supremacist groups like the Ku Klux Klan, especially after 1869 when President Ulysses S. Grant, the former Union general, took office. With federal protection, African Americans participated in local, state, and national elections, largely free from the political intimidation that had characterized the immediate post war years. The Republican Party, which had effected emancipation, enjoyed widespread and enthusiastic support within the African American community. Black politicians also 
joined the party, and some of them assumed positions of power and influence in local offices, state legislatures, and even the national government, with a small number elected to Congress. Southern whites still discriminated against and targeted African Americans, but as long as the U.S. army remained Republicans enjoyed significant power in the South. ${ }^{26}$ Unfortunately, northern patience for Reconstruction policies began to wane by the mid 1870's, as did their sympathy for African American southerners. A growing number of northern whites imagined a revitalized country united by race and economic dynamism. Democrats and increasing numbers of Republican politicians embraced the notion of white unity as a political tool. White reconciliation at the national level, however, ignored the plight of African Americans and undermined Republican political influence in the South. ${ }^{27}$

Military Reconstruction, and the protection it offered to African Americans and southern Republicans, ended in 1877. Southern white vigilante groups like the Ku Klux Klan reemerged and often used violent tactics to defraud and intimidate African American voters, undermining the ability of the Republican Party to organize. The suppression of the Black vote increased the political power of southern whites and the Democratic Party itself. The efforts of southern Democratic leaders, white vigilantes, and the growing influence of the Reconciliationist narrative brought all southern states under the banner of the Democratic Party by the early 1880s. The South became a region dominated by one political party, a situation that continued for decades and ensured the political, social, and economic subordination of marginalized African Americans. ${ }^{28}$ With the political supremacy of white southerners and the Democratic Party restored, the Lost Cause narrative appeared to have reached its fruition. 
The reality, however, proved more complicated. Marginalized African Americans actively resisted Democratic control and white supremacy. Across the South and despite the absence of federal protection, African American voters organized. Though they faced intimidation and violence, Black southerners sought to exert political influence. Even when white officials destroyed or altered African American votes, as frequently happened, the image of African American voters marching to the polls represented a potent challenge to white supremacy. The Democratic Party also faced resistance from poor white southerners, who likewise suffered from the predatory crop-lien system and the rapacious economic decisions of industrialists and businessmen. Beginning in Texas in the 1880s, many poor white and Black Southerners joined the Populists, a movement that encouraged cooperative buying and selling and the free coinage of silver. Southern economic elites and northern corporate leaders who exploited poor farmers and benefited from a politically docile labor force, viewed the Populist agenda with alarm. The Populists also directly challenged Democratic control of the South and thus represented a threat to the one-party political landscape of the region.

Historian Lawrence Goodwyn asserts that the Populist movement prospered because it reversed a widespread trend toward subservience among lower class people. ${ }^{29}$ Small scale landowners and tenant farmers refused to pay the exorbitant fees that railroad companies and financial institutions demanded. Goodwyn argues the Populist movement enjoyed success because it encouraged hope and self-respect in a largely disillusioned community. ${ }^{30}$ Goodwyn also demonstrates how communal resistance strategies improved the lives of marginalized peoples, threatened established business interests, and challenged the political status quo. The Populist Party enjoyed significant political 
success in the early and mid-1890s throughout the South. However, political divisions soon developed around the issue of free silver. In 1896, the Populist Party allied with the Democrats and nominated William Jennings Bryan for the presidency. After his defeat, the Populists could not agree on another candidate and the party dissolved, with many former supporters returning to the Democratic Party. Southern Democratic leaders however, had learned that issues of class could supersede issues of race, especially when Black and white farmers united around shared community interests. Fearing another political alliance between poor whites and Black, southern Democrats bolstered their hold on power by turning on African Americans.

Before the 1890's, southern whites used intimidation and violence to suppress African American political involvement. Indeed, such efforts had enabled the Democrats to take control in the late 1870 s. Yet Democrats remained unsettled by the specter of African American political participation, particularly in light of the Populist insurgency. Beginning in 1890, southern state legislatures began an aggressive campaign of legal disenfranchisement designed to deprive African Americans of their right to vote. The struggling Republican Party, which had moved away from its emphasis on racial equality, did little to stop the southern disenfranchisement campaign. Historian Glenda Gilmore shows how white elites in North Carolina took political control of the state and established Jim Crow laws that legalized segregation and discrimination. A similar process took place in every state across the South. Gilmore argues that the popular literature of the era, including the poetry of Rudyard Kipling, helped energize white nationalism and enshrine white supremacist dogma. ${ }^{31}$ Democratic propaganda demonized and dehumanized African American men by portraying them as a physical threat to the 
purity of southern white womanhood and employed charged language such as the word "vampire" to describe Black southerners. ${ }^{32}$ The Spanish-American War, Gilmore adds, played an important role in advancing white sectional reconciliation, justifying Black exclusion, and promoting an imperialist and racial ideology. ${ }^{33}$ The Democratic Party used these tactics to secure political power and remove southern African Africans from political life.

Still, African Americans continued to resist discrimination and political suppression. Gilmore argues that in the wake of disenfranchisement, African American middle class women assumed a new role, developing communities of support and advocating for African American men. Black women organized through churches and civic groups and worked to improve conditions within African American households. ${ }^{34}$ Within the domestic sphere, African American women emphasized education, recognizing that future political involvement depended upon literacy and knowledge. Likewise, African American communities and women's groups supported Black schools and other community projects. Equally important, African American women built relationships with white communities and civic leaders, often uniting with white middle class women around progressive ideas of cleanliness and sanitation. In effect, African American women became ambassadors to white culture, but always with the goal of improving the situation of the Black community. ${ }^{35}$ Gilmore's work shows how Black southerners exercised agency and actively sought educational, economic, and social opportunity despite political exclusion and in the face of a mounting climate of racial violence. 
While African Americans in the South faced the persistent threat of intimidation, violence, and even murder at the hands of southern whites, few of whom condemned the bloodshed. Instead, racial violence and the maintenance of white supremacy became an accepted aspect of southern life. Southern authorities often justified the racial violence by classifying African Americans as murderous or sexually threatening, emphasizing the vulnerability of white women to exaggerate their claims. However, most racial violence occurred when an African American individual or community challenged the white supremacist status quo. Thus, African American soldiers, politicians, or those who had achieved economic success became common targets for racist whites. ${ }^{36}$ Historians do not know exactly how many African Americans were targeted by white supremacist groups and mobs because many of the crimes and the identities of the victims went unrecorded. Scholars have concluded, however, that racial violence and particularly the practice of lynching, occurred far more than scholars had previously believed. ${ }^{37}$ The Equal Justice Initiative in Montgomery, Alabama has documented that at least 4,300 racially motivated lynchings occurred between 1877 and 1950. Whites employed lynching as a strategy to enforce segregation and ensure compliance with Jim Crow laws. ${ }^{38}$ White southerners used racial violence and the threat of violence, in short, to maintain social, political, and economic control over African Americans.

Historian George Wright details the wave of violence that African Americans in Kentucky faced between the Civil War and World War II. Wright argues that racial violence took many forms, including whipping, forcible removal from a community, the destruction of schools and property, the denial of a fair trial, and of course, murder. ${ }^{39}$ Wright also identifies patterns of racial violence across the state, in both rural and urban 
settings. In urban Louisville, for example, white supremacists targeted schools that educated African Americans. ${ }^{40}$ Instances of police brutality, informally sanctioned by the city government and the populace, became commonplace in Louisville and also ensured that African Americans remained second-class citizens. In every region of Kentucky, whites targeted African Americans who challenged white control by stepping outside of subservient roles. ${ }^{41}$ Even after state government intervention curtailed white supremacist groups like the Ku Klux Klan in the 1890s, Black Kentuckians still faced violent oppression. African Americans suffered less frequently from the rule of lynch law, but now, the state stepped in to administer the violence, trying African Americans defendants before hostile white juries that almost always convicted. According to Wright, this "legal lynching" served the same purpose - maintaining white supremacy - as the attacks by white mobs. ${ }^{42}$ In an environment of racial intimidation and violence, African Americans acted with extreme caution when they sought opportunities for employment and education.

\section{AFRICAN AMERICAN EDUCATION IN THE POSTBELLUM SOUTH}

In the antebellum South, few people beyond upper class whites has access to formal education. Certainly, no one without income or an elite sponsorship of some kind could hope to attain a higher education. Lower class whites usually gained some rudimentary education, often learned at home, but few small farmers in an agrarian society could afford to send their children to school or lose their labor in the fields for long. Children who assisted with farm work attended school only when the seasonal schedule of farm life permitted it. Predictably, most southern whites were poorly educated, though no legal prohibitions against their schooling existed. During the antebellum era, acquiring a 
formal education was neither realistic nor useful. ${ }^{43}$ Education became more important after the Civil War, as the South's economy became increasingly industrialized. The proliferation of new industrial processes, as well as the influx of tax revenue these new businesses provided, sparked the creation of new schools and universities across the South. Many white parents placed a new emphasis on their children's education because in a more complex world it afforded the opportunity for upward mobility. Educated whites filled the ranks of the postwar South's growing middle class, taking on skilled and well-paying jobs within the commercial and manufacturing sectors. Education and job discrimination denied these same opportunities to most African Americans who remained dependent upon the goodwill of educated whites.

Despite concerted efforts by whites to restrict African American educational opportunities, schooling remained a high priority for African American families and communities. Black southerners sought schooling for a variety of reasons, including acquiring political knowledge and increasing their employment and trade opportunities. Education, in short, provided the prospect of a better life, for both Black and white southerners. African Americans also sought education for what it represented. For freed peoples, kept ignorant and illiterate by their former masters, education meant freedom. To the newly enfranchised, education became a right of citizenship, as critical to African American freedom as the right to vote. ${ }^{44}$ The onset of legal disenfranchisement made education increasingly important within the African American community. For Black southerners who chose to migrate to the West or North, education offered the opportunity for more secure employment and a better chance of success. With the vote denied to most African Americans, education also became an avenue for restoring political rights. 
Educated Black southerners could circumvent the literacy test that disenfranchised them. For Blacks individuals not perceived as a threat to the racial status quo, education might also garner additional respect from whites. Northern businessmen who became key patrons of African American schools in the South also respected educated African Americans.

Historian James D. Anderson describes the development of southern Black education as disenfranchisement and other Jim Crow practices came to dominate the African American experience. Anderson argues that the collective effort of African American communities to build and support schools, refuted southern white assumptions about African American cultural ignorance and lethargy. Anderson demonstrates that marginalized African Americans resisted white supremacy by pursuing educational opportunities. Before emancipation, enslaved people often educated themselves in secret because southern slaveholders outlawed Black education and literacy. ${ }^{45}$ After emancipation, former slaves were the first southerners to advocate for universal and statesponsored education. When local and federal authorities proved slow to respond to these demands, African Americans established educational collectives, often based in Black churches and operated independently of white oversight, which taught large numbers of former slaves to learn how to read, write, and cipher ${ }^{46}$ Concerned white northerners also traveled South after the war to establish schools for the freed people, although these educators often brought their own racial assumptions about African American intelligence. ${ }^{47}$ Nevertheless, the number of Black schools in the South swelled considerably after the war. 
White southerners of all social classes resisted African American efforts to attain education. Elite whites realized that educated Black southerners threatened white control of African American labor while lower class whites recognized that educated African Americans challenged white supremacy and social control. Thus, whites of all social classes intimidated African American educators and violently oppressed Black communities that prioritized education. The compromise of 1877 , which ended military Reconstruction and halted federal protection of African Americans, enabled white southerners to take control of African American educational efforts and ensure white political, economic, and social dominance. ${ }^{48}$ In Kentucky, which had remained in the Union and thus never experienced military occupation during Reconstruction, white southerners banned integrated public education by constitutional amendment in 1866 , as historian John Hardin notes. In 1904, the state legislature passed the Day Law, which banned integrated education in private institutions. The law segregated Berea College, the last southern school to educate both races together. ${ }^{49}$ State officials were prepared to use violence to enforce the law, although both white and African American institutions responded with minimal resistance. Hardin argues African Americans opposed the passage of the Day Law but proved powerless to challenge the white elites who controlled the state legislature. ${ }^{50}$ Throughout the South, state legislatures used their control over school funding to segregate education.

Even in the face of intimidation and violence, Black Southerners remained determined to establish a system of education. Though they could not count on the support of the federal government to stop racial violence, African Americans developed an educational model that worked around and within these constraints. After the Civil 
War, white northerners introduced a new model of industrial education, focused on manual training and labor discipline rather than traditional liberal arts subjects. The industrial model represented a new if limited educational opportunity for African Americans, one adapted to the realities of African American life and inequality in the postwar and Jim Crow South. It also attracted the attention of a significant number of Black educators. Rather than antagonizing the white community and discouraging African American schooling, the industrial model promised to address African American demands for education while maintaining white control over the social and political spheres. The industrial model also appealed to many businessmen because it prepared African Americans for low-level jobs in white owned businesses. The patronage and advocacy of northern and southern white elites proved crucial for African American educators as they navigated the complicated world of marginalized education in a society that opposed racial equality. ${ }^{51}$

The industrial model of education originated at the Hampton Institute, founded in Virginia in 1868 by former Union General Samuel Armstrong. The Hampton Institute emphasized a rigid work schedule, meant to prepare students for lives of manual labor. The school also trained Black teachers, believing that instructors indoctrinated in the industrial model would teach it in their own schools. Hampton produced one of the most famous African Americans of the era, Booker T. Washington, who in 1881 established his own school, the Tuskegee Institute, modeled on Hampton. Washington rose to national prominence after he delivered his "Atlanta Compromise" speech in 1895. The address reflected Armstrong and Washington's accommodationist approach, which ceded African American political power and accepted segregation in return for potential 
economic advancement. ${ }^{52}$ Thanks in large part to Washington's efforts, as well as white approval and support, the industrial model spread across the South.

Black educators' dependence on white elites, both for financial support and to discourage acts of racial violence, required that they emphasize the industrial aspect of their curriculum. This strategy both mollified potentially violent whites and enabled African American educators to operate largely independent of white oversight. A model for this strategy could be seen in the Palmer Memorial Institute in North Carolina, founded and led by Charlotte Hawkins Brown. A savvy political operator, Brown's canny leadership of the school and selective deployment of the industrial model attracted white support while providing the means to resist white supremacy. Elite whites, attracted by Brown's association with prominent northerners, readily provided funding and patronage to the school. Brown also established cordial relationships with a variety of elite white women, many of whom assisted her efforts to gain support for the Palmer Institute. ${ }^{53}$

Taking advantage of her relationships with prominent whites also enabled Brown to challenge segregation and discrimination. Although the Palmer Institute was nominally an industrial school, Brown covertly educated her students in a traditional liberal arts curriculum. Working outside of white control, but benefitting from her relationships with prominent whites, Brown provided educational opportunities to her students that were usually denied to Black southerners. ${ }^{54}$ Not every industrial institution offered this sort of covert liberal arts education to African American students, but the industrial model nonetheless offered hope to African Americans who faced constant discrimination and racial violence. Black southerners hopes for enhanced educational and economic 
opportunities helps explain why the industrial model spread across the South. And because the industrial model also enjoyed the support of white elites many African American educators considered it the best opportunity for Black education in the South in the late nineteenth and early twentieth centuries. In Kentucky, where African American educators confronted strict legal educational segregation and limited funds, the industrial model became increasingly important.

Though African Americans in Kentucky faced racial constraints similar to those throughout the South, their proximity to the North and the growth of urban spaces like Louisville provided additional opportunities. In Kentucky's urban places, African Americans developed their own vibrant communities and support networks. Alarmed by the growing Black urban population and the consolidation of African American political and economic power, Kentucky's white leaders countenanced some Black educational opportunities in the form of industrial education. Although the African American community divided on the merits of the industrial model, many Black educators believed that it offered the most effective way to create educational opportunities in the context of Jim Crow. Consequently, African American leaders established a number of educational institutions across the state that adopted the industrial model. ${ }^{55}$

Eckstein Norton University, located south of Louisville in Cane Spring, Bullitt County, Kentucky, was among the Black schools organized on the industrial model and benefiting from the financial support of white elites. Opened in 1890, the university represented the hopes of the African American community, as well as the compromises necessary in a state where whites controlled almost every aspect of social, political, and 
economic life. The faculty and students of the university recognized the fragility of their hopes and the delicate nature of the compromise as they watched their main school building burn on that Sunday in 1892. After years of careful planning and frugal spending, their small school faced a financial crisis. Nevertheless, they continued to hope for a better future. As school President Parrish wrote in a published appeal for assistance only days after the fire:

"We therefore appeal to you as an institution of vigorous vitality, whose influence is already felt in preparing the youth for intelligent citizenship by educating the hand as well as the heart and head. The students are quite loyal, and say they will not leave, but put up with the present hardships and labor for the speedy rebuilding of better accommodations." ${ }^{, 56}$

In the face of a loss of property, both institutional and personal, the students and faculty persevered and successfully reopened the school. African American students continued to enroll in the school over the coming years, and many went on to receive their diplomas from the steady hand of Parrish. The story of Eckstein Norton University illuminates the experiences of Black southerners and demonstrates how African Americans fought for equality in the face of discrimination and marginalization.

\section{THESIS OUTLINE}

This thesis is comprised of three chapters. Chapter One examines the history of African American education in Kentucky, highlighting the restrictions imposed by the white state legislature and the methods by which African Americans attempted to secure educational opportunities. Chapter Two details the lives and careers of Simmons and Parrish, 
following them as they decided to create a new industrial school. Knowing that elite white patronage was crucial to their success, the two men searched for allies. They found social and economic support from Eckstein Norton and the L\&N Railroad. Chapter Three explores the operations of Eckstein Norton University. The school balanced white expectations with Black aspirations, lulling white observers while covertly embracing a liberal arts curriculum. The school's leaders used various methods to raise funds, although financial concerns never truly abated. Ultimately, Simmons and Parrish responded to restrictions on African American education through the use of the industrial model of education at Eckstein Norton University, enabling them to operate inconspicuously and provide further educational opportunities to Black Kentuckians.

1 "An Appeal for Aid: The Faculty and Directors of Eckstein Norton University Ask for Help toward Rebuilding," Courier-Journal, January 27, 1892.

${ }^{2}$ M. Bauerlein. (2004). Washington, Du Bois, and the Black Future. The Wilson Quarterly 28 (Autumn 2004), 75, 86.

3 John A. Simpson, "The Cult of the 'Lost Cause,'" Tennessee Historical Quarterly 34, no. 4 (1975): 350-61.

${ }^{4}$ David W. Blight, Race and Reunion: The Civil War in American Memory (Cambridge, MA: Belknap Press of Harvard University Press, 2001), 15.

${ }^{5}$ George Wright, Racial Violence in Kentucky, 1865-1940: Lynchings, Mob Rule, and “Legal Lynchings" (Baton Rouge: Louisiana State University Press, 1990), 19.

${ }^{6}$ Blight, Race and Reunion, 274.

${ }^{7}$ Ibid., 60. 
${ }^{8}$ Edward Ayers, The Promise of the New South: Life after Reconstruction (New York:

Oxford University Press, 1992), 6.

${ }^{9}$ Ayers, Promise of the New South, 12.

${ }^{10}$ Ibid., 13.

${ }^{11}$ Mathew Josephson, The Robber Barons: Great American Capitalists; 1860-1901 (New York Harcourt, Brace and Company, 1934), 94.

${ }^{12}$ Josephson, Robber Barons, 172.

${ }^{13}$ Ibid., 219.

${ }^{14}$ Ibid., 229.

${ }^{15}$ James D. Anderson, The Education of Blacks in the South, 1860-1935 (Chapel Hill

University of North Carolina Press, 1988), 153.

${ }^{16}$ Ayers, Promise of the New South, 429.

${ }^{17}$ Ibid., 197.

${ }^{18}$ Ibid., 13.

${ }^{19}$ Ibid., 253.

${ }^{20}$ Ibid., 429.

${ }^{21}$ Anderson, Education of Blacks in the South, 25.

${ }^{22}$ Ayers, Promise of the New South, 22.

${ }^{23}$ Anderson, Education of Blacks in the South, 33.

${ }^{24}$ Blight, Race and Reunion,46.

${ }^{25}$ Ibid., 47.

${ }^{26}$ Ibid., 49. 
${ }^{27}$ Ibid., 101.

${ }^{28}$ Anderson, Education of Blacks in the South, 34.

${ }^{29}$ Lawrence Goodwyn, The Populist Moment: A Short History of the Agrarian Revolt in America, (New York: Oxford University Press, 1978), 33.

${ }^{30}$ Goodwyn, Populist Moment, 35.

${ }^{31}$ Glenda Gilmore, Gender and Jim Crow: Women and the Politics of White Supremacy in North Carolina, 1896-1920 (Chapel Hill: University of North Carolina Press, 1996), 61.

${ }^{32}$ Gilmore, Gender and Jim Crow, 99.

33 Ibid., 63.

${ }^{34}$ Ibid., 153.

35 Ibid., 156.

${ }^{36}$ Wright, Racial Violence in Kentucky, 25.

${ }^{37}$ Ibid., 3.

${ }^{38}$ Equal Justice Initiative, Lynching in America: Confronting the Legacy of Racial Terror, ( $3^{\text {rd }}$ ed. (Montgomery, AL: Equal Justice Initiative, 2017); https://lynchinginamerica.eji.org/report/ (accessed Feb. 11, 2021).

${ }^{39}$ EJI, Lynching in America, 1.

${ }^{40}$ Ibid., 34.

${ }^{41}$ Ibid., 10.

${ }^{42}$ Ibid., 248.

${ }^{43}$ Anderson, Education of Blacks in the South, 4. 
${ }^{44}$ Hilary Green, Educational Reconstruction: African American Schools in the Urban South, 1865-1890. (New York: Fordham University Press, 2016), 16.

${ }^{45}$ Ibid., 16.

${ }^{46}$ Ibid., 7.

${ }^{47}$ Ibid., 12.

${ }^{48}$ Ibid., 23.

${ }^{49}$ John A. Hardin, Fifty Years of Segregation: Black Higher Education in Kentucky, 1904-1954 (Lexington: University Press of Kentucky, 1997), 13.

${ }^{50}$ Hardin, Fifty Years of Segregation, 23.

${ }^{51}$ Anderson, Education of Blacks in the South, 33.

${ }^{52}$ Harry Watson, "Front Porch." Southern Cultures 24, no. 2 (2018): 1-4.

${ }^{53}$ Gilmore, Gender and Jim Crow, 183.

${ }^{54}$ Ibid., 184.

${ }^{55}$ Hardin, Fifty Years of Segregation, 21.

56 "An Appeal for Aid: The Faculty and Directors of Eckstein Norton University Ask for Help toward Rebuilding," Courier-Journal, January 17, 1892. 


\section{CHAPTER 1 \\ FLAWED OPPORTUITIES: INDUSTRIAL EDUCATION IN JIM CROW KENTUCKY}

Eckstein Norton University opened its doors in 1890 with assistance from both the African American and elite white communities. The support of both groups proved vital to the school's formation, but the institution would not have succeeded without the dedicated actions of two African American men, William J. Simmons and his protégé Charles Henry Parrish. ${ }^{1}$ Both Simmons and Parrish lived and taught in Kentucky for several years before they created the school and had grown familiar with the difficulties facing African American education in the state. ${ }^{2}$ Their awareness of the history of Black education in Kentucky influenced their decision to establish Eckstein Norton as a school of industrial education. White elites in the state, those best positioned to offer protection and support to an African American school, favored the industrial educational model. Above all, industrial education, however flawed, presented an opportunity for the African American community. For Blacks in Kentucky, many of whom could not access quality public schools or higher education, a new school offered hope and opportunity. Still, Simmons and Parrish had to work hard to obtain funding and support from both the Black and white communities. This chapter will examine the history of African American education in Kentucky, from the Civil War to the creation of Eckstein Norton, 
demonstrating the extent of white opposition to Black education and the resistance strategies African Americans employed to overcome it.

\section{WHITE OPPOSITION IN THE POST-WAR PERIOD}

After the Civil War, African Americans in Kentucky who attempted to secure educational opportunities faced significant opposition from whites. White resistance to Black education included white Kentuckians in both the state government and the wider populace. Although the state of Kentucky never joined the Confederacy, whites in the state adopted a restrictive approach to African American education that resembled strategies used by the states of the Deep South. In Kentucky, as in other southern states, after the war, white state politicians moved quickly to gain control over African American educational opportunities, and they maintained their control for decades. In 1866, one year after the end of the Civil War, the Kentucky assembly passed legislation that enforced the racial segregation of public schools. ${ }^{3}$ The act separated the races at a young age, indirectly encouraging the spread of race-based misinformation and denying African American students the same educational opportunities offered to their white counterparts. Limited economic resources for African American students and schools exacerbated these educational disparities. The actions of the state legislature, which often defrauded African American schools or completely halted state support, further aggravated the economic problems facing Black schools. White politicians ensured that the taxes raised from both white and African American communities went first to schools that taught white children. These legislative practices effectively forced the Black community to support white students and schools while African American schools remained underfunded and poorly equipped. ${ }^{4}$ 
Despite extensive white resistance to African American educational efforts in Kentucky and across the South, Black communities in the post war era maintained their commitment to education by establishing grassroots schools. During Reconstruction, African Americans demonstrated their resolve by pushing the Republican Party to incorporate universal schooling into legislation. ${ }^{5}$ African Americans in Kentucky, despite the opposition of the state legislature, demonstrated a similar commitment to establishing educational opportunities in their communities. They knowingly paid extra taxes and willingly offered up their own goods, often lumber, to support the building of Black schools in their communities. ${ }^{6}$ Church leaders also assisted by converting their religious spaces into schools, making it easier for African American students to study and easing the strain on the Black community. ${ }^{7}$ Although the educational importance of religious institutions in Kentucky declined in the decades after the war, they played a crucial role during the 1860s and early 1870s. As Kentucky-based Freedmen's Bureau agent, T. K. Noble, remarked in 1867, "The places of worship owned by the colored people are almost the only available school houses in the state." ${ }^{\prime 8}$ Even as religious institutions became less central to African American educational efforts in Kentucky, they continued to play a significant role in the operation of smaller institutions such as Eckstein Norton University. ${ }^{9}$

In spite of the efforts of African American communities and institutions, the Kentucky state legislature continued to control and limit African American educational opportunities. Taxes from Black communities funded the education of white students, and most white politicians in the state legislature displayed apathetic or hostile responses to the development of educational opportunities for African Americans. The legislature's 
efforts to restrict Black education reflected the opinions of the majority of their white constituents, many of whom expressed concern that educated African Americans would challenge the racial status quo and threaten white supremacy. Importantly, these concerns also prompted many white Kentuckians to engage in racial violence to suppress challenges to white supremacy. White employers also feared African American education, believing that they would lose control over Black workers who had been emboldened by education. According to their reckoning, educated African Americans would be more likely to demand unionization and seek higher wages and better working conditions. ${ }^{10}$ In 1870, the Louisville Courier-Journal noted the importance of African American labor to the Kentucky economy. Alluding to racial violence and class conflict within a rapidly evolving economy, the newspaper stated, "But we do not want this sort of conflict, upsetting our domestic business, and disarranging our labor system, and entailing upon use and our children the worry, the uncertainty and the bad-blood of endless class legislation."11

Kentucky state legislators, sharing similar apprehensions and sensitive to the attitudes of their white constituents, strived to limit outside influences that might benefit African Americans. In the 1880s, when education became a topic of national interest and began to garner the attention of the U.S. Congress, southern political officials quickly took control of federal resources. The Inter-State Educational Convention of 1883, held in Louisville, emphasized the importance of southern legislative autonomy. The convention, which focused on meeting the evolving educational needs of the South, attracted delegates from across the United States. The delegation from Massachusetts included several members of the State Board of Education as well as Thos N. Bicknell, 
who led the Teachers Council of the United States and served as the editor of the highly influential New England Journal of Education. A representative of the Peabody Fund, specifically tasked with improving existing African American schools, also attended. The former president of the United States, Rutherford B. Hayes, could not attend the convention but wrote a letter that detailed his hopes for the gathering. The primary topic of debate at the convention revolved around the prospect of federal aid for southern schools. President Hayes and northern delegates, including those from Massachusetts, supported the measure, although they made it clear that southern delegates would ultimately decide the fate of their own region. ${ }^{12}$

Other topics of interest included the creation of common school systems and African American education. William J. Simmons, then the president of the Theological Seminary of Colored Baptists, later renamed State University, led the discussion on African American education. ${ }^{13}$ Ultimately, southern delegates decided to approve federal assistance to southern education, but delegates made it clear that the acceptance of such aid did not supersede southern legislatures' control over their states. ${ }^{14}$ As one of the delegates from Kentucky, A.S. Willis, noted, "The measures referred to do not claim for the Federal Government the right to control education in the State." ${ }^{\prime 15}$ Southern politicians, including those in Kentucky, were adamant about maintaining control over educational funds and thus African American schooling. Although African Americans in Kentucky still possessed the ability to vote, practices of voter repression and Black migration to points outside of Kentucky limited African American political power. The Democratic Party's ability to maintain a significant majority without catering to African American voters encouraged state lawmakers to defund and disregard African American 
schools. Even when a school building and financial resources could be procured, African American teachers could often not be found because segregation and lack of funding had resulted in a shortage of qualified instructors. The state legislature's efforts to segregate educational opportunities and defund African American education had resulted in a shortage of Black teachers. Furthermore, northern-based white aid societies that might have otherwise offered assistance or training focused their efforts on the educational problems of the Deep South. ${ }^{16}$

\section{AFRICAN AMERICAN RESISTANCE STRATEGIES}

African Americans in Kentucky, lacking significant support from the North and the state legislature, took it upon themselves to cultivate educational opportunities and increase the supply of Black teachers. Leaders in the African American community founded several important organizations that dedicated themselves to creating educational opportunities for Blacks and Black educators. The most significant of these organizations, the Kentucky General Association of Colored Baptists, formed in 1865. The group focused on the religious and secular training of African American ministers. It also served as an important center of discussion and debate for Black Kentuckians to consider the issue of education. ${ }^{17}$ Under the leadership of the Association of Colored Baptists, African Americans in Kentucky put pressure on local and state government officials to assist in the creation of a Black normal school or a school for the training of teachers. They insisted that the school be state sponsored because the Black community already paid taxes for the operation of white schools and could not endure additional financial strain. The Association of Colored Baptists joined with other African American organizations, such as the Kentucky Colored State Teachers Association, and advocated for additional 
educational resources. White politicians in the state legislature, however, continued to block any attempts to create an institution dedicated to the education of Blacks.

Change did not come until 1877, when the Superintendent of Public Instruction called a meeting of all African American educators in the state. The meeting gave new energy to Black educational efforts, particularly those of the Baptists, who continued to agitate for an institution that offered both theological and secular courses of study.

Without support from the state, African American education depended on the benevolence of religious whites. After attracting financial support from white Baptists, the Association of Colored Baptists opened the Kentucky Normal and Theological Institute in $1879 .{ }^{18}$ Located in Louisville, the school later altered its name to the State Colored Baptist University. The name change reflected the central role of the Baptist Church, as well as the fact that each state senator could send one student to the school on a state-sponsored scholarship. In the 1880s, the school added more comprehensive liberal arts courses to its curriculum, and it eventually became the primary institution of African American higher education in the state. Importantly, State University rejected the industrial education model and favored traditional liberal arts and theological curriculum. The religious association of the school and the backing of prominent white Baptists, may have permitted this deviation from the more widely accepted industrial model. ${ }^{19}$

At least partial credit for the success of State University must be attributed to William J. Simmons, who directed the school from 1880 to 1890. An able administrator, Simmons oversaw the absorption of several smaller African American educational institutions that lacked the financial stability of State University. Historian John Hardin identifies at least three private Black schools that merged with State University: Central 
Law School, Harper Law School, and the Louisville National Medical College. ${ }^{20}$ This pattern repeated itself in later years, as financial difficulties forced African American institutions to merge or dissolve completely. While working at State University, Simmons first met Parrish, his future protégé and collaborator. Originally a student at the school, Parrish served as an instructor at State University after his graduation. Both men also worked within the African American Baptist Church, and together they became a formidable pair of activists and administrators. ${ }^{21}$ Their religious connections and resources gave Simmons and Parrish an advantage as they competed for scarce financial resources and negotiated with a state legislature that became increasingly hostile toward African American education. The state legislature's control over Kentucky education and the depth of legislators' aversion to mixed race education became increasingly apparent in 1904, when the assembly passed the Day Law. Named after Democratic representative Carl Day, the law effectively ended any vestige of interracial education in the South when it prohibited private institutions from educating people of both races in the same room. ${ }^{22}$

\section{WHITE POLITICIANS DOUBLE DOWN}

The Day Law decreased the already limited educational opportunities available to African Americans. Kentucky formalized the segregation of public schools in 1866, but had thereafter allowed private institutions to teach Blacks and whites together. The state legislature, which controlled schools' purse strings and consequently the schools themselves, maintained educational inequality in the public school system but remained unable or unwilling to challenge private institutions that continued accept both African Americans and whites equally. Berea College, located in eastern Kentucky, was the only 
unsegregated institution in the state. Founded in 1858 by abolitionists John G. Fee and J.A.R. Rogers, the school began as an interracial institution, anti-slavery and anti-racist from its founding. As Fee asserted, "opposition to caste meant the co-education of the (so-called) 'races"', ${ }^{23}$ Berea College did not utilize the industrial model but instead employed a traditional liberal arts curriculum. Politicians in the state largely ignored the school for several decades, confident that widespread educational inequality in state funded public schools, economic disparity, and the continuing threat of racial violence would limit African American challenges to white supremacy. Moreover, the school's service to African Americans seemed on the decline. In 1899, the Indianapolis Recorder, a prominent African American newspaper that covered Black cultural events across the Midwest, reported with alarm: "Berea [KY] College is said to be drawing the color line in its selection of students. The ratio of colored and white students has always heretofore, been equal but the proportion of colored pupils now is small". ${ }^{24}$ Nevertheless, in Kentucky, where racial violence and legislation constantly threatened African American educational prospects, Berea's embrace of African American students, even in reduced numbers, along with its traditional liberal arts educational model was uncommon.

Berea College continued to accept African American students for over thirty-five years after the Kentucky state legislature banned mixed race education in public institutions and continued to do so until representative Carl Day stopped at the Berea railroad station in early 1904. Day, uncomfortable with any interaction between Blacks and whites, was shocked when he witnessed an embrace between two young African American women, one of whom Day thought was white. Both women attended Berea, and the young light-skinned woman was Black, but the damage was done. Day soon 
introduced a bill that banned the education of both races by private schools like Berea. In 1904, the Indianapolis Recorder entreated, "We hope that the governor of Kentucky will not hesitate in destroying the life of a bill recently passed in the legislature, providing for a separation of the races at Berea College; thereby destroying the usefulness and good work of that noble institution." ${ }^{25}$ Despite the opposition of African American educators and activists, as well as white allies like the administrators of Berea, the Day Law passed with only ten dissenting votes in the Kentucky state legislature. ${ }^{26}$ Black students in Kentucky would not learn alongside white students until the Supreme Court ruling on Brown v. Board of Education exactly fifty years later. ${ }^{27}$

To the distress of prominent African Americans in the state, Berea College, one of a small number of locations where African Americans could receive a liberal arts education, could no longer educate Black students. Despite the protests of alumni and both Black and white students, Berea complied with the Day law and forced African American students out of the school. William G. Fox, the president of Berea in 1904, came under fire from African American alumni who criticized his acquiescence. ${ }^{28}$ However, President Fox, observing the success of the industrial model at schools like the Tuskegee Institute, worked to salvage his reputation and that of his institution by opening an industrial offshoot of Berea College. Fox turned to philanthropists, both in the state and farther afield, for financial support. In February 1909, he told the Courier-Journal, “Everything depends upon Kentucky's response. . . I do not believe that this city [Louisville] or the State will fail to seize the opportunity set before it." ${ }^{29}$ Wealthy northern businessmen such as Andrew Carnegie contributed funds for the new school and local whites donated over forty thousand dollars. Despite ambivalence and sporadic 
protests from the African American community, the new school, Lincoln Institute, opened in $1911 .{ }^{30}$ Fox laid the cornerstone before returning to his post at Berea College ${ }^{31}$ The new institution educated the African Americans that Berea could no longer accommodate. ${ }^{32}$ For observers in Kentucky and around the nation, the segregation of Berea and the opening of the Lincoln Institute signified the influence of the industrial model in the South.

\section{INDUSTRIAL EDUCATION GAINS SUPPORT}

The passage of the Day Law and the segregation of Berea College forced African Americans in Kentucky to attend schools controlled or influenced by the state legislature. For the most part, this meant that Black Kentuckians either attended schools that utilized the industrial model or did not receive an education. The industrial approach to education, which focused on physical labor, differed widely from the liberal arts approach used at schools like Berea. Instead of preparing African American students for future professional careers, the model encouraged Black second-class citizenship. In effect, the industrial model promoted practices and values that benefitted white supremacy instead of African Americans. But with few of other educational opportunities and the support of white elites, African Americans in Kentucky and throughout the South reluctantly accepted the industrial approach. Historian James D. Anderson describes the industrial model as an "ideology designed to avoid. . . confrontations" with white elites and "maintain within the South a social consensus that did not challenge traditional inequalities of wealth and power."33

Fittingly, an elite northern white man, former Union General Samuel Armstrong, introduced the industrial approach to education. He tested the model at the Hampton 
Normal and Agricultural Institute, which he established in 1868 in Hampton, Virginia. Armstrong's interest in education stemmed from a background in Hawaiian missionary work, where he gained experience as an educator and administrator. Armstrong retained a racially paternalistic attitude and he considered it his duty to instill industriousness into young African Americans through rigorous labor and study. ${ }^{34}$ While speaking at a conference on race relations in 1890, Armstrong said, "Hard work is vital in a Christian community... The negro does not like to work because he has always had to"35 Armstrong believed that generations of enslavement had instilled an inherent indolence within African Americans and that only an industrial education could alter their character. He refrained from mentioning - though his audience understood - that this style of education provided laborers for white businesses and promised more effective control of that labor.

At Hampton Institute, Armstrong emphasized physical labor by strictly controlling almost every hour of the students' lives. Students in the Night School, the largest program of the institution, labored for as long as ten hours per day and then devoted several hours at the end of the day to academic studies. As Booker T. Washington, Armstrong's most celebrated student and advocate, wrote, "During my last year at Hampton every minute of my time that was not occupied with my duties as janitor was devoted to hard study." ${ }^{36}$ An avowed believer in the superiority of the white race, Armstrong also claimed that manual labor would instill morality and dignity in his students, qualities which he argued most African Americans did not possess. ${ }^{37}$ Armstrong labored to spread the industrial model of education throughout the South and used the Hampton Institute to train African American teachers, believing that the industrial 
approach would spread through the lessons of his students. ${ }^{38}$ Washington, Hampton's most famous and successful student, trained to be a teacher at Hampton and graduated in $1875 .^{39}$

Washington later worked at Hampton as the teacher of the Night School and the superintendent of the Native American dormitory, where by his own account he achieved considerable success and drew the favorable attention of Armstrong. ${ }^{40}$ In 1911, the former Union general nominated Washington for a position in Tuskegee, Alabama, to lead a new industrial school for African Americans. Prominent whites in Tuskegee, concerned about the migration of African Americans out of their county, decided to create an educational institution to keep Blacks and their labor in the community. ${ }^{41}$ They approved of Armstrong's industrial model and of Washington himself, who opened the Tuskegee Normal School for Colored Teachers on July 4, 1881. The Virginia and Alabama schools had many similarities. Both institutions embraced the value of industriousness and emphasized daily labor, although Washington avoided the underlying white paternalism and racialism that guided Armstrong and Hampton. Students at Tuskegee worked regularly on campus agricultural plots and made and sold bricks that they fashioned in a kiln with materials from a nearby clay deposit. As Washington later described his educational philosophy: "we wanted to give them [the students] such a practical knowledge of some one industry, together with the spirit of industry, thrift, and economy... We wanted to teach them to study actual things instead of books alone."42

Some students at Tuskegee and Hampton voiced objections to the industrial model, specifically the emphasis on manual labor. Several young African Americans studying at Hampton Institute entered the school with the assumption that they would 
learn a skilled trade, and became discouraged when they were assigned menial labor. To several of the students and parents, it seemed that the vocational school focused on establishing a broad but shallow understanding of many trades, rather than an in-depth knowledge of a specific trade. ${ }^{43}$ Academic courses did not offer a well-rounded liberal arts education, but instead prepared primary school instructors to teach the industrial education philosophy. Tuskegee faced similar criticisms from both parents and students, notwithstanding the significant bulwark of Washington's personality. As Washington remembered, "we began facing in an emphasized form the objection of the students to being taught to work... Quite a number of letters came from parents protesting against their children engaging in labor while they were in the school. Other parents came to the school to protest in person." 44

Despite the reservations of many students and parents to the emphasis on manual labor, the industrial model spread throughout the South. Many of the teachers trained at Hampton and Tuskegee went on to open their own schools and promoted the benefits of the industrial approach. Washington became the leading advocate of the movement, gaining national distinction after he delivered his famous "Atlanta Compromise" speech in 1895. His address argued that African Americans should avoid northern resettlement. Repeating the phrase "cast down your bucket where you are" from Herman Melville's Moby Dick, Washington pleaded with African Americans to stay in the South. He maintained that racial equality would come through the labor of African Americans, but only after they had applied themselves to the "education of head, hand, and heart." 45 Washington argued that Black and white southerners possessed shared interests and he called for the "interlacing [of] our industrial, commercial, civil, and religious life with 
yours in a way that shall make the interests of both races one. ${ }^{\circ 6}$ Washington stressed that Black southerners must first prepare themselves for the exercise of full civil rights. "The wisest among my race understand," Washington argued, "that agitation of questions of social equality is the extremest folly... It is important and right that all privileges of the law be ours, but it is vastly more important that we be prepared for the exercise of these privileges. ${ }^{\$ 47}$ Washington viewed industrial education as the means through which African Americans could establish their niche in southern society and prepare themselves for eventual racial equality. The speech emphasized Armstrong and Washington's accommodationist approach, ignored the ongoing racial violence directed at Black southerners, and ceded African American political power in favor of potential economic advancement. ${ }^{48}$ Southern whites, particularly those in elite circles, quickly embraced the idea.

White northern elites also became key supporters of the industrial model of education. Allying with wealthy white southerners, they provided valuable financial assistance as well as access to larger social networks of philanthropists and businessmen who could offer further assistance to the schools. Both Armstrong and Washington maintained strong relationships with prominent white philanthropists. These ties, both financial and social, guaranteed steady financial support and enabled Armstrong and Washington to continue to advocate for their industrial model of education. Washington wrote extensively of his early struggles to establish his Alabama school, particularly his efforts to secure funding to purchase the initial supplies needed to teach and care for students. The school had significant need for such support, as Washington described in his autobiography, Up from Slavery: 
"The weather during the second winter of our work was very cold. We were not able to provide enough bed-clothes to keep the students warm. . . I recall that on several occasions I went in the middle of the night to the shanties occupied by the young men, for the purpose of comforting them. Often I found some of them sitting huddled around a fire, with the one blanket which we had been able to provide wrapped around them, trying in this way to keep warm." 49

At times, financial concerns necessitated personal sacrifices from the students and staff. On one memorable occasion, lacking funds for the building of a new brick kiln, Washington traveled to Montgomery and pawned his pocket watch. He received fifteen dollars for the watch, enough to finance the building costs, but never regained his watch because he could not raise enough money to buy it back. ${ }^{50}$

Facing mounting costs, Washington turned to the man who had first started him on his path as an educator, General Armstrong. As Washington later recalled, "At one time, when we were in the greatest distress for money that we ever experienced, I placed the situation frankly before General Armstrong. Without hesitation, he gave me his personal check for all the money which he had saved for his own use. This was not the only time that General Armstrong helped Tuskegee in this way." ${ }^{51}$ Armstrong continued to provide support for Washington's school, and later introduced him to many influential white philanthropists and aid societies. ${ }^{52}$ As Washington admitted, the success of the Tuskegee Normal School would not have been possible without the support of Armstrong and the white businessmen and philanthropists with whom he associated. The support of white elites, including members of southern state legislatures, proved crucial for the 
continued success of the industrial model in the South. Industrial schools across the region, including within Kentucky, depended on white approval and assistance.

In Kentucky, both private and public funds supported schools following the industrial model. The most substantial private donations came from elite white supporters of the industrial approach, a pattern of philanthropy that grew after Washington's 1895 Atlanta speech ${ }^{53}$ Public support came from the state legislature, although this support was sporadic and not all industrial schools received state assistance. Schools that could not remain financially viable without support from public funds had to merge with larger institutions, following the pattern begun in the late 1880s when State University absorbed several smaller institutions. ${ }^{54}$ Competition over private and public funds increased as more schools for African Americans appeared in Kentucky. The first publicly supported school for Blacks in Kentucky, the Kentucky State Normal School for Colored Persons, was founded in 1886. By 1890, the institution's use of the industrial model had attracted the attention and financial support of prominent whites. The president of Kentucky State, John Henry Jackson, had received a traditional liberal arts education at Berea College but he recognized that his institution depended upon elite white patronage and that these sponsors approved of the industrial model. To secure white support, Jackson embraced the industrial approach, although observers of both races recognized that it encouraged the racial status quo. ${ }^{55}$ The state legislature continued to provide funds for the growth of Kentucky State, passing laws in 1893, 1896, and 1897 that benefitted the school. ${ }^{56}$ In 1902, reflecting the growing acceptance of industrial education within the African American community, school leaders changed the name of the school to the Kentucky Normal and Industrial Institute. ${ }^{57}$ The change not only reflected the growing importance 
of industrial education within the African American community, but it also demonstrated that African American educators recognized that an association with industrial education could garner more support from elite whites.

Despite the financial benefits, not all members of the African American community supported the industrial approach. Several prominent Black Kentuckians expressed their reservations, observing that industrial education would disadvantage African American students and empower social and economic inequality. ${ }^{58}$ African Americans across the South, including the prominent scholar and activist W. E. B. DuBois, also shared these concerns. ${ }^{59}$ DuBois publicly renounced the industrial model, becoming the most well-known critic of Washington's views. Not content to wait and peacefully labor until racial equality arose naturally, DuBois routinely denounced racial violence and supported the burgeoning civil rights movement. The debate between Washington and DuBois drew the attention of both African Americans and whites, creating headlines across the nation. The Raleigh-based North Carolinian summarized the southern white perspective on the debate: "Washington's party is the party of the opportunist and optimist. . . Dr. DuBois' party, on the other hand, represents the critical point of view. . . a parity of agitation, emphasizing rights rather than duties."60

Notwithstanding the concerns of DuBois and many African Americans Kentuckians, educators like Simmons and Parrish accepted the industrial model, largely because they saw it as the only viable educational option for African Americans in the racially segregated South. It also gave Black educators connections to prominent whites who could assuage hostile southerners and offer financial support. As historian John Hardin writes, African American educators' "advocacy of industrial education gave them 
credibility among powerful white philanthropic agencies and, in turn, respect among fellow blacks for being connected with powerful whites." ${ }^{\prime 61}$ Enthusiasm for the industrial model among both elite whites and certain members of the African American community prompted the creation of new industrial schools in the state and led existing schools to adopt the industrial model.

In the western part of Kentucky, African Americans had limited access to higher education. Kentucky's 1866 decision to enforce segregated education in public schools meant that they could not attend any of the all-white institutions in the area. Berea College offered an opportunity for education before the passage of the Day Law, but enrollment was too expensive and remote for most African Americans in western Kentucky. Likewise, the Kentucky Normal and Industrial institute, formerly Kentucky State, was too far removed from western Kentucky to make enrollment a viable option for many Blacks in the region. ${ }^{62}$ Educational opportunities for African Americans in the western part of the state remained limited until 1909, when D. H. Anderson started the West Kentucky Industrial College for Colored Persons. ${ }^{63}$ A native Tennessean, Anderson moved to Paducah in 1893. For years, he sought financial support from wealthy whites in the region, but the rising costs of education eventually convinced him in 1912 to appeal to the state legislature. Several white politicians within the state legislature approved of the industrial model and offered support for West Kentucky Industrial College, although others remained hesitant to fund any type of African American school. An intense debate ensued in the state assembly, lasting six years, but the overwhelming need for a regional school and the attraction of the industrial approach won over enough white legislators. In 
1918, the state government agreed to fund Anderson's school, offering him three thousand dollars per year. ${ }^{64}$

African American students and parents continued to express dissatisfaction about the industrial approach to education. Like the students and parents at Hampton and Tuskegee who grew disillusioned by the focus on labor instead of liberal arts education, many Black Kentuckians had concerns about the industrial curriculum. The Courier Journal recorded one such complaint from 1915: "A new student arrived at the State Normal and Industrial Institute for Colored People near this city, was handed a list of studies from which to select the ones he wished to pursue... and was set to work plowing. He protested that he could learn farming at home and did not know that they called it agriculture up here." ${ }^{65}$ The educational debate within the African American community spread beyond the polarizing figures of Washington and DuBois. Julia Young, the editor of a local African American newspaper, the Kentucky Standard, became an outspoken critic of the industrial model in Kentucky. She insisted that African American students should have the opportunity to receive both industrial and traditional liberal arts training. Her anti-industrial education convictions led to her to publish an article in the Indianapolis Freeman, a widely circulated African American newspaper. Young wrote, "Why is it that the Negro can't have an academic, normal, and college training as well as toting the wood and digging the soil? ... Such questions are now being asked by the people of the city and state."

In Kentucky, prominent educators such as Simmons and Parrish stood at the center of the discussion. Despite his ten years of success at Kentucky State, Simmons knew that African Americans in the state still lacked qualified teachers and sufficient 
educational prospects. Simmons concluded that the industrial model offered the best chance to expand educational opportunities and financial assistance for African Americans in a region characterized by racial inequality and violence. ${ }^{67}$ Along with his protégé, Parrish, Simmons resigned from his position to start a new school in Cane Spring, about twenty miles south of Louisville. Believing that elite whites would support the effort, the two men began to scour the region for financial support. ${ }^{68}$ As the Louisville Courier Journal wrote, "The plans were feasible and practical, but these men had not [the means] with which to carry out their plans. ${ }^{" 69}$ Armed with instructional and administrative experience, a knowledge of both the white and African American communities, and a plan that circumvented the limitations of the white legislature, Simmons and Parrish set out to create their school.

1 "A Kentucky Tuskegee: Good Work Done at the Eckstein Norton School," The Courier Journal, May 18, 1902; "Eckstein Norton,” The National Magazine: A Monthly Journal of American History 5 (1892): 88.

${ }^{2}$ C. H. Parrish, Golden Jubilee of the General Association of Colored Baptists in Kentucky: The Story of 50 Years' Work from 1865-1915 Including Many Photos and Sketches, Compiled from Unpublished Manuscripts and Other Sources (Louisville: Mayes Print, 1915), 182-84, 284, 285.

${ }^{3}$ John A. Hardin, Fifty Years of Segregation: Black Higher Education in Kentucky, 19041954," (Lexington: University Press of Kentucky, 1997), 2.

${ }^{4}$ Ibid., 2.

${ }^{5}$ James D. Anderson, The Education of Blacks in the South, 1860-1935, (Chapel Hill University of North Carolina Press, 1988), 20. 
${ }^{6}$ Hardin, Fifty Years of Segregation, 2.

${ }^{7}$ Ibid, 2.

${ }^{8}$ Anderson, Education of Blacks in the South, 13.

${ }^{9}$ Lee L. Brown, A Short History of Eckstein Norton, 1911, Eckstein Norton File, Bullitt County Historical Society, Shepherdsville, Kentucky (hereafter BCHS).

${ }^{10}$ Anderson, Education of Blacks in the South, 96.

11 "The Negroes of Kentucky," Courier-Journal., February 19, 1870.

${ }^{12}$ R. B. Haves, "Educational: Arrival of Delegates to the Inter-State Convention, which Assembles in this City this Forenoon, Views of Prominent Educators," Courier-Journal, September 19, 1883.

13 "Educational: The Programme of Exercises for the Inter-State Convention, Which Meeting To-Morrow-Meeting of School Commissioners Night Schools Organized," Courier-Journal, September 18, 1883.

${ }^{14}$ W. M. Beckner, et al., "Education: Last Day's Proceedings of the Interstate Convention of Eminent Public Educators, the Proposed Refunding of the Cotton Tax to the States for School Purposes Voted Down, Governmental Aid for the Tuition of the Illiterate Masses Approved by a Large Majority, the State Committee on the Revision of the School Laws Submits Its Report, Which is Adopted, the Educational Question Discussed," CourierJournal, September 22, 1883.

15 "Education: Help for Colored Schools," Courier-Journal, September 21, 1883.

${ }^{16}$ Hardin, Fifty Years of Segregation, 3.

${ }^{17}$ Ibid., 3.

${ }^{18}$ Ibid., 3 . 
${ }^{19}$ Ibid., 4.

${ }^{20}$ Ibid., 4.

${ }^{21}$ Parrish, Golden Jubilee, 182-84, 284, 285.

${ }^{22}$ Hardin, Fifty Years of Segregation, 12.

${ }^{23}$ Paul David Nelson, "Experiment in Interracial Education at Berea College, 1858-1908," The Journal of Negro History 59, no. 1 (1974): 15.

24“"Berea College,” Indianapolis Recorder, August 5, 1899.

25 “The Governor of Kentucky,” Indianapolis Recorder, February 6, 1904.

${ }^{26}$ Hardin, Fifty Years of Segregation, 13.

${ }^{27}$ Ibid., 109.

${ }^{28}$ Ibid., 16.

29 "The Lincoln Institute." Courier-Journal, February 9, 1909.

${ }^{30}$ Hardin, Fifty Years of Segregation, 16.

31 “President Frost, of Berea College, Laying Corner Stone of Berea Hall, Lincoln Institute (Negro) in Shelby County," Courier-Journal, October 26, 1911.

${ }^{32}$ Hardin, Fifty Years of Segregation, 21.

${ }^{33}$ Anderson, Education of Blacks in the South, 33.

${ }^{34}$ Ibid., 33.

35 “The Efficacy of Work," Courier-Journal, June 15, 1890.

${ }^{36}$ Booker T. Washington, Up from Slavery (New York: Doubleday, 1901), 51.

37 “The Efficacy of Work," Courier-Journal, June 15, 1890.

${ }^{38}$ Anderson, Education of Blacks in the South, 34. 
${ }^{39}$ Louis R. Harlan, Booker T. Washington: The Making of a Black Leader, 1856-1901, (New York: Oxford University Press, 1972), 77.

${ }^{40}$ Harlan, Washington, 103, 105.

${ }^{41}$ Ibid., 112.

${ }^{42}$ Washington, Up from Slavery, 88.

${ }^{43}$ Anderson, Education of Blacks in the South, 59.

${ }^{44}$ Washington, Up from Slavery, 108.

45 "Atlanta Compromise Speech," New Georgia Encyclopedia:

http://www.georgiaencyclopedia.org (accessed March 11, 2021).

${ }^{46}$ Ibid.

${ }^{47}$ Ibid.

${ }^{48}$ Harry Watson, "Front Porch," Southern Cultures 24, no. 2 (2018): 1-4.

${ }^{49}$ Washington, Up from Slavery, 117.

${ }^{50}$ Ibid., 106.

${ }^{51}$ Ibid., 102.

${ }^{52}$ Ibid., 125.

${ }^{53}$ Hardin, Fifty Years of Segregation, 6.

${ }^{54}$ Ibid., 4.

${ }^{55}$ Ibid., 5.

${ }^{56}$ Ibid., 6.

${ }^{57}$ Ibid., 26.

${ }^{58}$ Ibid., 22.

${ }^{59}$ Anderson, Education of Blacks in the South, 65. 
60 "New Southern Statesmanship," The North Carolinian (Raleigh) August 13, 1908.

${ }^{61}$ Hardin, Fifty Years of Segregation, 25.

${ }^{62}$ Ibid., 28.

${ }^{63}$ Ibid., 28, 29.

${ }^{64}$ Ibid., 29.

65 "In Kentucky: Not What He Wanted." Courier-Journal, March 13, 1915.

${ }^{66}$ Hardin, Fifty Years of Segregation, 23.

${ }^{67}$ Ibid., 24.

68 "The Beginnings of Eckstein Norton University," Eckstein Norton File, BCHS.

69 “'A Kentucky Tuskegee: Good Work Done at the Eckstein Norton School," Courier Journal, May 18, 1902. 


\section{CHAPTER 2}

\section{A "FEASIBLE AND PRACTICAL" PLAN: TWO EDUCATORS BEGIN THEIR}

\section{JOURNEY}

The Reverends William J. Simmons and Charles Henry Parrish both grew up under the yolk of slavery. ${ }^{1}$ Freedom, much less the freedom to pursue an education, remained outside their reach so long as their futures were controlled by the whites who owned their bodies and claimed to own their minds. Both men suffered at the hands of white slaveholders, but once freed they battled racism and discrimination, received college degrees, and became prominent religious and academic leaders. This chapter will examine the lives of Simmons and Parrish, highlighting their educational and religious experience. Ultimately, these factors influenced their careers, their aspirations, and the methods by which they sought support for the new school.

Simmons, the more experienced leader of the duo, displayed a talent for leadership and learned how to navigate through both African American and white communities as a renowned minister and later as president of State Colored Baptist University in Louisville, Kentucky. ${ }^{2}$ Simmons led State University ably for ten years after 1880, while other African American educational institutions closed around him. ${ }^{3}$ Charles H. Parrish, Simmons's close friend and protégé, remained at State University after graduating in the mid-1880s, helping his mentor to educate African American students and teachers. ${ }^{4}$ The two men, respected in their communities and known 
nationally, obtained their education even as whites attempted to eliminate such opportunities for African Americans. Working together at State University, they devoted their careers to educating marginalized African Americans, giving hope and opportunities to many Black Kentuckians. Their decision to leave State University and start their own industrial school came as a surprise to many, particularly individuals concerned with African American education. ${ }^{5}$ Although welcomed by many elite whites, the industrial model of education generated significant debate within the African American community. Many Black leaders across the country and in Kentucky criticized the industrial model and questioned Simmons and Parrish's decision. ${ }^{6}$

The industrial model, applied in African American higher education throughout the South after Reconstruction, had significant limitations. The approach emphasized labor instead of traditional liberal arts subjects, a shift in focus that encouraged African American second-class citizenship. The industrial model represented a compromise between African Americans who fought for educational opportunities and whites who tried to stifle political or economic opportunities for Blacks. ${ }^{7}$ In the late nineteenth century, African American educators and activists in Kentucky struggled to overcome the resistance of the all-white state legislature. The widespread application of the industrial model in Kentucky began not because the approach proved especially beneficial to African Americans, but because it represented the only educational opportunity that white citizens and politicians would allow Black residents to pursue. ${ }^{8}$ Thus, by the time Booker T. Washington delivered his famous "Atlanta Compromise" speech in 1895, at least two industrial schools existed in Kentucky and many more had been established across the South. ${ }^{9}$ 
Black educators, administrators, and activists in Kentucky recognized the limitations of the industrial model and the way it compromised their aspirations. They actively debated the merits of industrial education, echoing the debate between Booker T. Washington and W. E. B. Du Bois. Many concluded, however, that African American education and the use of the industrial model in Kentucky had already been decided by forces beyond their control. Notwithstanding the ferocity of the debate within Kentucky and the South, the educational needs of African Americans increased while opportunities decreased. In 1910, at least 30 percent of African Americans in the South remained illiterate ${ }^{10}$ The creation of normal schools such as the State Colored Baptist University barely addressed the shortage of African American teachers, a particularly pressing problem in Kentucky. ${ }^{11}$ African American leaders knew that the state desperately needed another normal school to meet the growing demand for trained teachers. Some educators concluded that the industrial model represented the only opportunity for the creation of a new school that would educate the teachers so badly needed by Black Kentuckians. Additionally, the white community's endorsement of the industrial approach made elite white patronage or perhaps even support from the state legislature more likely.

As experienced educators and administrators living in Louisville, the center of African American cultural life in Kentucky, Simmons and Parrish recognized the limitations of the industrial model and followed the ongoing debate among their colleagues. However, Simmons and Parrish concluded that the industrial model represented an opportunity -the best available to African Americans in the Jim Crow South -to further improve African American educational prospects in the state of Kentucky. Committed to the improvement of their communities and armed with the 
conviction that education played a crucial role in individual and group success, the two men decided to start their own industrial and normal school. The creation of an independent school that would improve African American educational opportunities represented a challenging undertaking for two men who had already risen so far from their modest beginnings.

\section{THE LIVES OF SIMMONS AND PARRISH}

Much of the information regarding Simmons and Parrish's lives before their tenure at State University comes from Golden Jubilee of the General Association of Colored Baptists in Kentucky: The Story of 50 Years' Work from 1865-1915, edited by Parrish and published in 1915. Parrish assembled the document on the occasion of the fiftieth meeting of the General Association of Colored Baptists in Kentucky, the religious assembly to which both Simmons and Parrish belonged. In 1915, Parrish was both editor and moderator of the association. ${ }^{12}$ The manuscript offers a rare look at the lives of African American religious and educational leaders, like Simmons and Parrish, born into slavery and educated in the Jim Crow South. Washington, the man most associated with the industrial model, told his story in several autobiographies. The stories of Simmons and Parrish, who also rose from slavery, became leaders in Kentucky, and employed the industrial model in the state, are told in Golden Jubilee.

Simmons was born on June 29, 1849 in Charleston, South Carolina. His parents, Edward and Esther Simmons, were enslaved, but escaped to Philadelphia when Simmons was a young boy. In 1860, over twenty-two thousand free African Americans resided in Philadelphia, making it a relatively safe space for escaped slaves. Still, whites in Philadelphia rioted against the Black community six times in the years before the Civil 
War and racial violence erupted frequently. ${ }^{13}$ The Simmons family stayed in hiding, avoiding violent whites and slave catchers who would try to return them to their former owner. Simmons could not attend the local public schools, but received private lessons from his uncle, a "very good scholar" who instilled in Simmons "a foundation so broad and exact that college studies were comparatively easy." ${ }^{14}$ In 1862, Simmons apprenticed to a dentist in New Jersey. He later attempted to enter a dental school in the North but was rejected because of his race. Unwilling to return to his job as a dental assistant, Simmons enlisted in the Union Army, joining the $41^{\text {st }}$ United States Colored Infantry Regiment on September 16, 1864. Simmons's regiment participated in the battles of Petersburg and Appomattox Courthouse. At Appomattox, Simmons witnessed Confederate General Robert E. Lee's surrender of the Army of Northern Virginia to Union General Ulysses S. Grant. After the war ended, Simmons spent the next two years in New Jersey, before attending Madison University of New York and Rochester University, his education financed by wealthy white patrons from his biracial church. This act of generosity from sympathetic northern whites may have encouraged him to appeal to white patrons during his later career as an educator and administrator. At the very least, the financial assistance of his patrons allowed Simmons to continue his education until eyesight problems compelled him to step back from his studies for a period of time. ${ }^{15}$

Simmons returned to the academic world in 1871 and graduated from Howard University in 1873. After graduation, Simmons began his long career in education by teaching school outside of Washington, D.C. Within a few years, Simmons had risen to become principal of Hillsdale Public School and married Josephine Silence. The young 
couple moved to Florida in 1874, but found their financial prospects limited. Rather than remain in Florida, Simmons became an ordained minister in 1879 and moved his family to Lexington, Kentucky. ${ }^{16}$ A year later, Simmons was appointed president of the Normal and Theological Institute, later renamed the State Colored Baptist University, a position he held for ten years. ${ }^{17}$ When Simmons first arrived in 1880 , the school had only two educators, thirteen enrolled students, and no financial resources. Simmons quickly began to improve the school's facilities, increase enrollment, and raise funds. ${ }^{18} \mathrm{He}$ demonstrated an ability to administer and improve educational institutions, burnishing his reputation as an educator and community religious leader. Religion and education remained constants in Simmons life and influenced all his decisions. He became a well-known writer and speaker, receiving honorary degrees from Wilberforce and Howard Universities. ${ }^{19}$ His reputation grew after he released a well-received book of biographical essays entitled Men of Mark. ${ }^{20}$ Simmons's national influence and renown, as well as his considerable intellect and experience navigating a segregated world, made him uniquely suited to the task that he and Parrish began. The pair would need all of Simmons's experience as they opened a new school in the face of a hostile state legislature and the constant threat of racial discrimination and violence.

Less is known about Parrish's early life. As editor of Golden Jubilee, he may have omitted subjects that he considered inappropriate for a church document. Parrish was born into slavery on April 18, 1859, ten years after Simmons. He lived the first years of his life on a Kentucky plantation owned by Beverly A. Hicks. Parrish formally became a Christian in 1869 and was baptized at First Baptist Church in Lexington. Ten years later, Simmons arrived in Lexington as the new pastor of the church. ${ }^{21}$ Parrish's early 
experiences with education were lackluster. He attended an African American school for several years but dropped out in 1874 to work as a railway porter. Still, Parrish possessed a keen mind and he maintained an interest in education and religion. He developed a close friendship with Simmons after the minister assumed control of First Baptist Church in Lexington, and he followed Simmons to Louisville when he became the president of State University in 1880, where he prospered. Graduating in 1886 as valedictorian from State University, he received one of only three Bachelor of Arts degrees awarded by the institution that year. ${ }^{22}$ The small number of African American degree recipients reveals the lack of educational opportunities available to Blacks in Kentucky. ${ }^{23}$ The Louisville Courier Journal, which reported on Parrish's graduation, wrote, "The valedictorian, Charles H. Parrish, who selected 'The Analysis of Thought' as his subject, treated it in a very scholarly manner, quoting extensively from Locke, Darwin, Herbert Spencer, and other masters of thought... President Simmons then presented the prizes and afterward conferred the degree of Bachelor of Arts upon the three graduates."24

Parrish decided to remain at State University, where he taught Greek and worked closely with Simmons, acting as the president's secretary and co-treasurer of the school. As agents of State University, the two men became visible symbols of African American intellectualism. The Kentucky Advocate, a white newspaper in Danville, reported on the educators' purchase of small farm outside of Lexington, writing that the two men "will presumably be an addition to the learning of our city, as Professor Parrish requested to be furnished with a copy of [Greek author] Aeschylus in the original, with which he occupied himself while the bond was being written." 25 Parrish also became deeply involved in the African American Baptist Church, where he assumed a variety of 
leadership roles. He also preached at Calvary Baptist Church in Louisville for thirty years and founded the National Baptist Convention. ${ }^{26}$ Later in life, Parrish traveled extensively for religious purposes. The Golden Jubilee recounted his international travels in some detail: “ [Parrish] traveled in the Holy Land, [was an] Oriental Pilgrim in River Jordan, April 13, 1904. Delegate to Baptist World's Congress, 1904. Messenger to World's Sunday School Convention, Jerusalem, 1904.Preached in seventeen towns in Germany... six hundred converts. ${ }^{27} \mathrm{He}$ also received honorary degrees from State University, Central Law School in Louisville (part of State University), and the Royal Geographical Society in London, England. ${ }^{28}$ Simmons was the more experienced of the two men, especially in academic administration and fundraising, but Parrish's life experiences, youth, and determination to improve African American education made him a valuable partner in the creation of the new school.

\section{RELIGION AND RESISTANCE}

In addition to offering biographical information, the Golden Jubilee accentuated Simmons and Parrish's focus on religion and the development of their religious community. Both men ministered within the Baptist Church for many years. While a student in the early 1880s, Parrish became a popular guest minister at African American churches in the Lexington area. ${ }^{29}$ White newspapers and the Golden Jubilee reveal the prominent leadership positions that both men held in the Baptist Church, but the latter publication reveals how Simmons and Parrish used religious ties to gain community support and develop new frameworks of resistance to segregation and white supremacy. Washington believed that African Americans could attain economic success only through accommodation with white leaders and thus refused to speak publicly against racial 
oppression, concerned that doing so would endanger his school and philosophy. As Washington wrote in "The Religious Life of the Negro," a widely circulated 1905 article: "It was natural and inevitable that the Negro Church, coming into existence as it did under slavery, should permit the religious life of the Negro to express itself in ways almost wholly detached from morality." ${ }^{30}$ A devotee of the Hampton Institute ideal of morality through labor, Washington was clearly uncomfortable with the concept of redemption and racial uplift through religious commitment. He added, "A large element of the Negro Church must be recalled from its apocalyptic vision back to the earth; the members of the Negro race must be taught that mere religious emotion that is guided by no definite idea and is devoted to no purpose is vain." ${ }^{31}$ Students at both the Hampton Institute and the Tuskegee Normal School attended regular school-sponsored church services, the practice in part reflecting a desire to conform to contemporary social standards and an effort to control the schedules of their students when they did not have classes.

Speaking through a religious lens that few whites acknowledged or questioned, Parrish could be more direct than Washington in his criticism of racial prejudice. In the Golden Jubilee he wrote, "Human Rights will be obtained even though the way lie through oppression," 32 adding, "Where Christians live up to the Gospel standard, race prejudice is unknown. Christianity is incompatible with caste." ${ }^{33}$ His criticism of fervently Christian but racist white southerners in such passages is apparent. Indeed, his condemnation of white racism would have endangered his own safety and threatened the future of the educational institutions he led if not enfolded within a book intended for a predominately African American readership. In the same text, he also offered a veiled 
criticism of the industrial model of education, writing, "The only prize worth contending for, in this world is men and all things else -all trade, all commerce, all industry, all government, all pleasures that do not contribute to the making of men -must rest under his [God's] displeasure." 34 Parrish's status as a religious leader, rather than educator, made his critiques of white racism, Jim Crow policies, and the industrial culture of the post-war South possible.

Parrish's statements in the Golden Jubilee, although written almost thirty years after he graduated from State University, illuminate how religion inspired and directed his and Simmons's resistance to white supremacy. Both men opposed the existing racial status quo and their decision to establish a new school using the industrial approach did not indicate an acceptance of racial deference or subservience. Instead, inspired by their faith, both men believed that utilizing the industrial model could subvert the segregation and marginalization of African Americans. Admittedly, Washington also hoped that industrial education would end segregation, but he lacked the spiritual foundation and support from the Black religious community that empowered Simmons and Parrish. For Kentucky educators, the industrial model of education -as a means to improve African American educational opportunities -and their religious convictions were not mutually exclusive. Rather, the two men demonstrated the intertwining of education, religion, and racial uplift. As Parrish wrote in the Golden Jubilee, "He [the Lord] showed Simon in the presence of a penitent woman that his gospel recognized no infallible Jerusalem Standard or 'Privileged Class' that looked down on others." 35

\section{CREATING THE NEW SCHOOL}


In 1890, Simmons and Parrish left their positions at State University to establish the new institution. ${ }^{36}$ Both men had received a traditional liberal arts education, but had come to believe that in the racially segregated post-Reconstruction South the industrial model offered the best chance to improve the educational prospects of African Americans. They expected wealthy whites within the state legislature and private circles to support an industrial school. With years of experience as a popular writer and speaker, Simmons could reach out to elite whites, not as a social equal, but as a respected and intelligent representative of the African American community. Simmons's experience as a fundraiser and school administrator made the idea of a new school with him at the helm appear viable to prospective donors. Parrish's impressive academic record and connections to local religious organizations also strengthened the efforts of the two men as they began to search for financial assistance.

Still, the two educators encountered immediate obstacles. The African American community, still divided over industrial education, proved unable or unwilling to donate enough money to purchase land or establish school facilities. The state legislature, too, refused to finance a second African American industrial school after it had provided the funds for the creation of Kentucky Normal and Industrial Institute for Colored Persons in 1886. ${ }^{37}$ As the Louisville Courier Journal wrote, "The plans were feasible and practical, but these men had not [the means] with which to carry out their plans." 38 Facing the collapse of their endeavor before it began, Simmons and Parrish reached out to private citizens in Louisville, hoping to identify wealthy whites who would provide the necessary funds. They soon found their sponsors at one of the most prominent businesses in the region, the Louisville and Nashville Railroad. 
By the time Simmons and Parrish approached the company, the L\&N Railroad had been in operation for forty years. Starting in 1850, the company linked Louisville with the markets of the Deep South and transformed the smaller towns and cities along its path. ${ }^{39}$ The company grew over the years, expanding its services and lines. By 1890 , they employed a large workforce, including members of the African American community. However, African American L\&N employees faced significant difficulties. Discriminatory hiring practices excluded many Blacks from the higher paying jobs available to white employees and facilities for African American workers were limited and segregated. ${ }^{40}$ In the years before 1890 , mismanagement, particularly a propensity for speculative business deals, along with administrative disagreements and corporate infighting, left the company deeply in debt and on the verge of bankruptcy. ${ }^{41}$ Still, the company managed thousands of miles of track and continued to transport people and goods across the southeastern United States. The railroad could return to profitability if the managers could devise a viable and cohesive business plan. In 1886, conflict between the company's president Milton Smith and the northern-based board reached a crescendo. The board decided to replace Smith with Eckstein Norton, the first vice-president of the company, and a man with a proven track record of managing successful businesses. ${ }^{42}$

\section{ECKSTEIN NORTON AND THE L\&N RAILROAD}

The new president of the L\&N railroad was born in Russellville, Kentucky, on December 16, 1831. Norton's parents could not afford to send him away to receive a private education and thus his first educational experiences took place in a small common school in western Kentucky. ${ }^{43}$ With slavery legal in Kentucky and no government provisions for the education of free African Americans, Norton's early experiences included no 
interactions with Black students. From the age of fifteen, Norton worked, first as a clerk in a general store in Russellville. Three years later, he opened his own competing business in a nearby location, exhibiting the skills needed to manage a business successfully. By 1857, Norton had worked as a receiving and forwarding agent for the Illinois Central Railroad Company and started a mercantile house and a bank in Paducah. In 1864, as the Civil War drew to a close, Norton moved to New York City, and established a successful bank, E. Norton \& Co. ${ }^{44} \mathrm{He}$ remained in New York for several years, but invested in various southern railroads and business. In 1868, he purchased the Paducah \& Gulf Railroad and facilitated the building of a line from Elizabethtown to Paducah. Norton soon united these two rail lines and then sold them to the larger Chesapeake, Ohio, and Southwestern railroad..$^{45}$ By 1880, Norton had proven that he could successfully manage a profitable business in both the North and the South.

In the 1870s, Norton became acquainted with L\&N executives in New York who recognized his business abilities and appointed him liaison between foreign investors and L\&N executives in Kentucky. He soon rose to the position of vice president and with the railroad faltering in 1886, the board promoted Norton to president of the company. An experienced businessman and banker, Norton's credentials impressed the board members in New York, while his tactful dignity and background in Kentucky endeared him to company executives in the South. Norton moved quickly to consolidate the company and return it to profitability, an effort lauded by investors and interested businessmen across the country. As The National Magazine wrote in 1892, “Since Mr. Norton's connection with the company it has risen from a condition of impaired credit and depreciated stock, until now its credit and standing are excellent and it is classed among the good dividend- 
paying properties of the country." ${ }^{, 46}$ While president of the L\&N Railroad, Norton and his family lived in Louisville. ${ }^{47}$

Simmons and Parrish's search for wealthy white patrons willing to offer financial assistance to their school brought them to the Louisville based executives of the L\&N, including Norton, who showed interest in their idea. Though born in Kentucky, Norton shared the sentiments of many northern elites who supported African American industrial education. Additionally, the L\&N Railroad employed African American workers. Supporting a school for African Americans signified an executive interest in the wellbeing of its Black workers and their families. Encouraged by Norton, individual executives and the company donated to the school. Norton personally contributed five hundred dollars, while the eleven other white executives donated a combined one thousand and fifty dollars. The company itself donated another fifteen hundred dollars from the profits of the railroad. ${ }^{48}$ The Courier Journal wrote of the contribution: "Eckstein Norton, President of the Louisville and Nashville railroad, showed his interest in the race and their welfare by contributing liberally to the establishment of the institution." ${ }^{49}$

\section{INTRODUCING CANE SPRING}

Altogether, Simmons and Parrish raised over three thousand dollars from the $\mathrm{L} \& \mathrm{~N}$ and its executives, enabling them to search for a suitable property on which to build their school. State University, which Simmons and Parrish had recently left, was based in Lexington and the area had no need for another African American normal and industrial school. African Americans in western Kentucky enjoyed few educational opportunities, but the small Black population made the region an unpromising location. A school in western 
Kentucky would have difficulty attracting a sufficient number of students who could pay tuition, jeopardizing any school's financially viability. Louisville also lacked a normal and industrial school, but was home to a growing African American population. Thus, Simmons and Parrish chose to locate their new school close to Louisville. The two men purchased a property in Cane Spring, Kentucky, about twenty-nine miles south of the city, near Shepherdsville. Locating the school near Louisville, Parrish and Simmons believed, would enable them to appeal more readily to the city's white elites for further financial assistance. Additionally, both potential patrons and students, could conveniently visit the new industrial school.

The Cane Spring property purchased by Simmons and Parrish, soon to become the central campus of their new school, originally belonged to Austin and Georgia Speed. The property consisted of about seventy acres, including a brick house, maple grove, and fruit orchard. The Courier Journal described the site as, "one of the healthiest in the State, being on a lofty hill one mile from Cane Spring." ${ }^{, 50}$ The Speed family agreed to sell the land for 4,750 dollars and Simmons and Parrish paid over half the initial cost in cash. using the money donated by Norton and the L\&N Railroad. ${ }^{51}$ The two men could now put their expertise as educators and administrators to work and begin the organization of their new institution.

\section{NAMING THE SCHOOL}

Among the first questions Simmons and Parrish addressed was selecting the name of the school, which must reflect the industrial approach to avoid angering whites alarmed at the prospect of African Americans receiving an education. Current and potential financial contributors likewise expected the school name to emphasize the industrial approach, 
similar to the renaming of State University to Kentucky Normal and Industrial Institute. ${ }^{52}$ Simmons and Parrish also sought to honor their primary patron, and doubtlessly recognized the benefits of associating their university with a prominent Kentucky businessman. Still, the two men did not lose sight of their ultimate objective, the improvement of African American educational prospects. Thus, the title of the school also needed to reflect this goal and attract interest from the African American community. The name they chose, Eckstein Norton University of Sciences, Professions, Arts, and Trades, reflected these various considerations.

But Simmons and Parrish's decision also reflected a common pattern among African American educational institutions in the South, many of which were named after a prominent white individual or family. The Rosenwald school building program, financed by Julius Rosenwald and a variety of wealthy northern whites, stimulated the construction of African American schools across the South. The fund and the schools that it helped create continued to bear Rosenwald's name even though northern money covered less than half the cost of each school. Likewise, Simmons and Parrish's new school bore the name of its most prominent white patron even though African Americans contributed significantly larger amounts of time and effort to the creation and management of the institution. ${ }^{53}$ Other African American educators also recognized the advantages of an association with elite whites. Charlotte Hawkins Brown, the leader of a prominent industrial school in North Carolina, used this technique to garner for herself and her institution further influence among white elites. Before opening her school, Brown had connected with the well-known educator Alice Freeman Palmer, famous in northern educational circles for her advocacy of women's education. Brown had enjoyed 
a brief relationship with Palmer, who had expressed interest in supporting Brown's new school before she passed away while traveling in Europe. When news of Palmer's death reached Brown, she named her new school the Palmer Memorial Institute. ${ }^{54}$ Brown's decision to dedicate her institution to Palmer's memory reflected a variety of factors. First, she realized that ties with the prominent white educator would help her secure financial assistance from northern white elites. In addition, Brown capitalized on her school's association with northern philanthropy to encourage southern whites to assume financial responsibility for her school. Appealing to southern pride, she challenged southern whites to a philanthropic competition with the North and consequently reaped donations from elites in both regions. ${ }^{55}$

Simmons and Parrish had similar motives in naming their new school after the influential businessman who financed the purchase of their school. In a state shaped by white supremacy and segregation, in which the flawed industrial model represented the best option for improving African American educational opportunities, Simmons and Parrish recognized the benefits of an association with Norton. Naming the school after the prominent and respected Kentucky-born business executive linked the school to the Norton family and to the L\&N Railroad, enhancing its prestige and assuring prospective donors and students of the school's continuing stability and respectability. The connection also set Simmons and Parrish's school apart from State University, which was associated with the African American church rather than a distinguished white patron. Finally, Simmons and Parrish likely hoped that the Norton name would mitigate possible conflicts with local whites who frowned on Black education of any sort. But the association with the Black school also reflected well on a successful businessman like 
Norton and the company he directed. Norton's support of the school increased his personal prestige, but also indicated that the formerly struggling L\&N Railroad had achieved a degree of financial stability. Despite any personal or professional gains that the donation may have given Norton, his support of the new school undoubtedly reflected his genuine support for Black industrial education. Indeed, his family continued to donate to the institution after Norton's death in 1893, reflecting the sincerity of his commitment. ${ }^{56}$

Norton enjoyed enhanced prestige from having a school named in his honor, but Simmons and Parrish hoped for a far more significant return from their decision. Starting an African American school in Kentucky in the late 1890s, even one embracing the industrial model, remained a difficult task. Financial strains, a recalcitrant state legislature, and hostile white residents constantly threatened the new school. Naming their school after Norton, Simmons and Parrish hoped, would ease the difficulties they faced. The name would attract additional financial patronage, enabling Simmons and Parrish to limit financial challenges and dependence on a racist state legislature. They also anticipated that white citizens who accepted the industrial approach would be further assuaged by the association of the school with an elite white businessman. Likewise, the two educators hoped that the white community would perceive attacks on the schools, its students and teachers, as an assault on Norton and his legacy, and would consequently discourage racial violence. In short, Simmons and Parrish believed their name choice would help ensure the longevity of their school and the safety of their students and staff. Discrimination and the tenets of the industrial model circumscribed Simmons and Parrish's endeavor, but taking the name and donations of a prominent white businessman 
like Norton made the success of their efforts to expand educational opportunities for African Americans in Kentucky more likely.

\section{A GRAVE BEGINNING AT CANE SPRING}

Eckstein Norton Industrial University, funded by prominent white supporters and managed by two African American educators, quickly coalesced on the site of the old Speed family home. The brick building standing on the property underwent a transformation. It now held the classrooms, administrative offices, and served as the dormitory for female students and staff. ${ }^{57}$ Following the industrial approach that the school adopted, Simmons and Parrish also purchased farm equipment. The construction of blacksmith and carpentry workshops further added to the industrial capabilities of the school. ${ }^{58}$ The chief patrons of the school, Eckstein Norton and the L\&N Railroad, contributed to the school's early success by building a new railway station at Cane Spring, constructed specifically to service the university's faculty and students ${ }^{59}$ Both the community of Cane Spring and the university benefitted from the connection to a wider railroad network. The community enjoyed enhanced access to goods, services, and job opportunities, and the school more readily attracted new students because of the Cane Spring Depot. Students from Louisville and beyond could travel easily to Eckstein Norton, as could potential donors who wished to see the campus. Simmons and Parrish could now begin the work that inspired them: teaching African American students, and training much needed teachers and qualified industrial workers. The two men opened their new school on a Sunday, October 5, 1890. The inaugural class consisted of twentyfour students, taught by sixteen African American instructors. ${ }^{60}$ 
But the new school soon faced its first trial. Weeks after Eckstein Norton University opened, Simmons became gravely ill. On October 26, the Courier Journal reported:

The Rev. Wm. J. Simmons, one of the best known colored men of this State, is lying at the point of death at his home in this city. His sickness has been of long standing, and is due, it is thought, to over exertion... Since yesterday morning he has grown so much worse that his death is hourly expected." 61

Simmons lingered for four more days, but on October $30^{\text {th }}$ succumbed to his illness and passed away. Simmons's death was a grievous loss for the campus and the broader African American community. After his passing, the Louisville Courier Journal noted, "A large number of telegrams of sympathy were received yesterday from all parts of the United States." 62

Simmons's remains lay in state at his former school, State University, for several days. Hundreds of people paid their respects to the man who had done so much for African American education in the state. The funeral was held on November 3, almost a month after Simmons and Parrish had opened Eckstein Norton University together. The Courier Journal described Simmons's funeral as follows: "Under a canopy of green and in a massive bed of flowers the casket was placed. It was of rich black cloth, with silver ornaments, but was almost hidden from view by floral tributes that rested upon the lid... the church was so crowded that standing room could not be found." ${ }^{, 63}$ Parrish delivered a sermon, praising the deceased for his educational and religious accomplishments. ${ }^{64}$ 
The New York Times, far from Simmons's southern home, acknowledged his influence and the gravity of his passing in its October 31 obituary, which read:

"William J. Simmons, President of Eckstein Noton [sic] Industrial College for colored youths, died near Louisville, Ky., yesterday. Dr. Simmons was for ten years President of the colored State University of Louisville, and for several years past District Secretary of the American Baptist Home Mission. . . He was born in Charleston S.C. and was forty-one years old." ${ }^{\prime 65}$

That an African American educator merited mention in one of the nation's largest newspapers reveals Simmons's standing in both the African American and white communities. In contrast, the Times obituary spelled Eckstein Norton's name incorrectly, omitting the "r" in Norton. The obituary defined Simmons's life by his educational and religious work rather than his race or the assistance of elite white sponsors. Simmons wielded considerable influence in Kentucky and the new school would not have come into existence without his strength of will and perseverance. Parrish provided valuable assistance, but Simmons had always been the older and wiser tutor in their relationship. As Parrish wrote, "He was a friend to the poor student and infused inspiration among many. His name will ever live among Negro Baptists." ${ }^{\prime 66}$ Barely a month after the opening of the school, Parrish had lost his mentor and partner. Facing a volatile world and beset by financial, political, and social challenges, Parrish had to manage the new school on his own. He now faced the daunting challenge of managing, administering, and fundraising for the new school without Simmons's experience and social and political connections. But Parrish's subsequent actions revealed no hesitation. He remained 
committed to Eckstein Norton University and to creating new educational opportunities for African Americans in Kentucky.

${ }^{1}$ C. H. Parrish, Golden Jubilee of the General Association of Colored Baptists in Kentucky: The Story of 50 Years' Work from 1865-1915 Including Many Photos and Sketches, Compiled from Unpublished Manuscripts and Other Sources (Louisville, Mayes Print, 1915), 182, 284.

${ }^{2}$ Ibid., $182-84$.

${ }^{3}$ John A. Hardin, Fifty Years of Segregation: Black Higher Education in Kentucky, 19041954, (Lexington: University Press of Kentucky, 1997), 4.

${ }^{4}$ Parrish, Golden Jubilee, 284.

${ }^{5}$ Ibid., 184.

${ }^{6}$ Hardin, Fifty Years of Segregation, 17,18.

${ }^{7}$ James D. Anderson, The Education of Blacks in the South, 1860-1935 (Chapel Hill:

University of North Carolina Press, 1988), 44.

${ }^{8}$ Hardin, Fifty Years of Segregation, 13.

${ }^{9}$ Ibid., 6.

${ }^{10}$ Anderson, Education of Blacks in the South, 34.

${ }^{11}$ Hardin, Fifty Years of Segregation, 3.

${ }^{12}$ Parrish, Golden Jubilee, 1.

${ }^{13}$ Theodore Hershberg, "Free Blacks in Antebellum Philadelphia: A Study of Ex-Slaves, Freeborn, and Socioeconomic Decline," Journal of Social History 5, no. 2 (1972), 184, 185.

${ }^{14}$ Parrish, Golden Jubilee, 182. 
${ }^{15}$ Ibid., 183.

${ }^{16}$ Ibid., 183.

${ }^{17}$ Hardin, Fifty Years of Segregation, 4.

18 “Simmons, William J.," The Encyclopedia of Louisville, John Kleber, et al., eds.

(Lexington: University Press of Kentucky, 2001), 822.

${ }^{19}$ Parrish, Golden Jubilee, 184.

${ }^{20}$ Hardin, Fifty Years of Segregation, 24.

${ }^{21}$ Parrish, Golden Jubilee, 284.

${ }^{22}$ Hardin, Fifty Years of Segregation, 25.

23 “Colored Graduates: Commencement Exercises of the State University," Courier-

Journal, May 20, 1886.

24 Ibid.

25 “Danville and Vicinity,” Kentucky Advocate, January 6, 1888. p. 6.

26 “Parrish, Charles Henry Sr.," Encyclopedia of Louisville, 695.

${ }^{27}$ Parrish, Golden Jubilee, 284.

${ }^{28}$ Ibid., 284.

29 “Colored Graduates: Commencement Exercises of the State University," Courier-

Journal, May 20, 1886.

${ }^{30}$ Booker T. Washington, "The Religious Life of the Negro," The North American

Review 181, no. 584 (1905): 21.

${ }^{31}$ Washington, "Religious Life," 22.

${ }^{32}$ Parrish, Golden Jubilee, 15.

33 Ibid., 34. 
34 Ibid., 14.

35 Ibid., 29.

${ }^{36}$ Hardin, Fifty Years of Segregation, 25.

37 Ibid., 26.

38 “A Kentucky Tuskegee: Good Work Done at the Eckstein Norton School”, Courier Journal, May 18, 1902.

${ }^{39}$ Maury Klein, History of the Louisville and Nashville Railroad, (New York: The Macmillan Company, 1972), 5.

${ }^{40}$ Carl Ryant, "'Where the Railroad Was, the River Is'": Oral History from L\&N Workers." The Register of the Kentucky Historical Society 82, no. 1 (1984), 66.

41 “Eckstein Norton,” The National Encyclopedia (1891), Eckstein Norton File, Bullitt County Historical Society, Shepherdsville, Kentucky (hereafter BCHS).

${ }^{42}$ Klein, History of the Louisville and Nashville Railroad, 240.

43 “Eckstein Norton," The National Encyclopedia (1891), Eckstein Norton File, BCHS.

${ }^{44}$ Klein, History of the Louisville and Nashville Railroad, 240.

${ }^{45}$ Ibid., 241.

46 "Eckstein Norton," The National Magazine: A Monthly Journal of American History 5 (1892), 88.

${ }^{47}$ Klein, History of the Louisville and Nashville Railroad, 241.

48 “The Beginnings of Eckstein Norton University,” Eckstein Norton File, BCHS.

49 "Eckstein Norton University." Courier-Journal, March 15, 1896.

50 Ibid.

51 “Eckstein Norton University Land and Donations," Eckstein Norton File, BCHS. 
${ }^{52}$ Hardin, Fifty Years of Segregation, 26.

${ }^{53}$ Anderson, Education of Blacks in the South, 154.

${ }^{54}$ Glenda Gilmore, Gender and Jim Crow: Women and the Politics of White Supremacy in North Carolina, 1896-1920 (Chapel Hill: University of North Carolina Press, 1996), 180.

${ }^{55}$ Glenda, Gender and Jim Crow, 183.

${ }^{56}$ Lee L. Brown, “A Short History of Eckstein Norton,” 1911, Eckstein Norton File, BCHS.

57 "An Appeal for Aid: The Faculty and Directors of Eckstein Norton University Ask for Help toward Rebuilding,” Courier-Journal, January 27, 1892.

58 "Eckstein Norton University." Courier-Journal, March 15, 1896.

59 “Eckstein Norton University,” Eckstein Norton File, BCHS.

${ }^{60}$ Ibid.

61 “The Rev. Simmons Dying,” Courier-Journal, Oct 26, 1890.

62 "To Be Buried Monday: Final Services Over Remains of the Late Rev. Dr. W. J. Simmons," Courier-Journal, November 1, 1890.

63 “The Last Rites: Final Services Over the Remains of the Late Rev. Dr. W. J. Simmons the Funeral One of the Largest Ever Taking Place in the City," Courier-Journal, November 4, 1890.

${ }^{64}$ Ibid.

65 “Obituary,” New York Times, October 31, 1890, p.

${ }^{66}$ Parrish, Golden Jubilee, 184. 


\section{CHAPTER 3}

\section{"RUINING GOOD PLOW HANDS": THE WORK OF ECKSTEIN NORTON}

UNIVERSITY

After years of planning and painstaking fundraising, the industrial school envisioned by William Simmons and Charles Parrish had finally been realized. The new school, christened Eckstein Norton University, opened with an inaugural class of twenty-four students in $1890 .{ }^{1}$ The new school offered a wide array of courses, covering both industrial and liberal arts subjects, although by necessity the industrial program appeared the most important, especially to white observers. Throughout his tenure as president, Parrish maintained a delicate balancing act, reassuring whites that the racial status quo would remain unchanged while the school did its utmost to improve the educational prospects of Black Kentuckians. Financial viability remained critical to the success of this mission, leading Parrish to employ various enrollment and fundraising strategies that neither Hampton nor Tuskegee used. This chapter will examine these methods, demonstrating how inventiveness and an ability to meet white expectations, while quietly deviating from certain aspects of the industrial model, became key factors in the success of the school and the fulfillment of its mission.

Notwithstanding the sudden shock of Simmons's death, Eckstein Norton University quickly became a second home to many. Students and faculty lived on the Cane Springs campus and saw the maple trees that surrounded the school change colors 
as fall proceeded. The average temperature during the winter of 1890 was 47.6 degrees, over ten degrees warmer than the previous year, making it easier for faculty and staff as they learned to care for their students in a new environment. ${ }^{2}$ The success of the school depended not only upon the effective education of the students, but also on the ability of the staff to provide adequate housing and nourishment. Successfully housing students both justified the cost of room and board and attracted additional students. Moreover, the long term financial viability of the school necessitated charging for room and board and attracting larger numbers of students. The school's early success in these matters, as well as the educational opportunities it offered, clearly caught the attention of the region's African American community because enrollments continued to rise as the year progressed. According to the 1911 Eckstein Norton Catalog, a total of fifty-two students enrolled in the 1890 school year, with an additional twenty-eight students joining the inaugural class of twenty-four. ${ }^{3}$ The doubling of enrollment reflected the schools growing reputation among African Americans in Kentucky. Despite continuing debates about the merits of industrial education, a growing number of African Americans believed that the new school could both educate and care for the students who lived on the Cane Spring campus. The standing and efforts of Simmons and Parrish within Kentucky's Black community contributed to the early success of the school, which again doubled its enrollment, to ninety-seven students, in $1891 .{ }^{4}$

Interested white Kentuckians also watched the school during its first year of operation, although few cared about the educational opportunities offered to African Americans. Instead, they monitored the growth of Eckstein Norton University to ensure that it adhered to the standards and practices of industrial education. In effect, white 
Kentuckians wanted to ensure that the new school did not teach Black students to challenge the racial status quo. The Louisville Courier Journal, catering to its white audience, described the school's first commencement, which took place on June 17, 1891. The article praised the students and staff, but it also reflected the racial prejudices and concerns of the white community. "The aims of the institution," the newspaper reported, "are thoroughly practical and the whole system and curriculum is opposed to a theoretical education which will give to the average colored man or woman aspirations and appreciation beyond their station."

To secure the goodwill and possible financial assistance of white Kentuckians, Parrish needed to mitigate hostility and distrust. To do so, Parrish regularly invited whites from the surrounding area to campus ceremonies to secure community support. Commencement ceremonies and celebrations such as Donor's Day became opportunities to bring sympathetic whites to the campus and associated facilities such as Parrish's Calvary Baptist Church. Parrish cultivated a relationship of trust with whites in the region to ensure that Eckstein Norton University could operate with minimal oversight. He wanted to ensure that he and the other African American members of the faculty controlled the day-to-day operations of the new school.

\section{THE CURRICULUM AND SCHEDULE AT CANE SPRING}

Knowing that his financial supporters and the broader white population expected the new school to focus on industrial education, Parrish ensured that Eckstein Norton University offered a variety of industrial courses, including courses in dressmaking, sewing, cooking, printing, shoe-making, painting, carpentry, barbering, laundry, and farming. ${ }^{6}$ Gender determined both living quarters and the courses in which a student enrolled. 
Women students, housed in the main brick structure on the campus, typically received training in dressmaking, sewing, and what school catalogs classified as "housework." In addition to their education in the classroom, women students also worked as domestic laborers in local households. As the Courier Journal wrote, "This gives the pupils a source of revenue and at the same times furnishes them experience." 7 The classes offered, in short, reflected the gendered assumptions of the era and thus both in and out of the classroom women's industrial training centered on the creation of garments or the maintenance of the home.

The limited nature of women's educational opportunities contrasted with the more varied options offered to men, who could choose between shoe-making, painting, carpentry, barbering, blacksmithing, farming, and commercial (or business) training, which included shorthand and typewriting. ${ }^{8}$ Notably, business courses did not prepare students for careers as business owners but reflected racist expectations that trained African Americans would work for white-owned businesses. Other industrial training such as farming and barbering prepared African Americans for more independent careers, but school administrators, seeking to maintain cordial relations with regional whites, did not emphasize such options. Agricultural students maintained the campus gardens and raised crops on the surrounding land. Not only did the work of these farming students help defray the cost of food at the school, but they also generated positive publicity for the institution. On one occasion, the Courier Journal reported, "The vegetables and fruit are as fine as are raised in the country, and at the last fair potatoes grown at the institution were awarded the first prize." ${ }^{\prime 9}$ Industrial courses such as blacksmithing also contributed to the self-sufficiency of the school. Firmly ensconced as the head of the institution after 
Simmons's death, Parrish recognized the importance of the industrial curriculum in placating a white population hostile to the idea of Black education.

As at other industrial schools such as Hampton and Tuskegee, the industrial approach to education at Eckstein Norton extended beyond the classroom. Hampton's Samuel Armstrong and Tuskegee's Booker T. Washington maintained that industrial education must emphasize both physical labor and a strict student schedule, claiming that it would build mental discipline. ${ }^{10}$

Thanks to Armstrong and Washington's example, when Eckstein Norton University opened its doors in 1890 the industrial model of education had become synonymous with stringent student schedules and disciplined timetables. The African American community expected their children to maintain an orderly schedule, although they expressed concern when laborious tasks appeared to supersede students' academic training. Wishing to preserve current enrollment and attract future students, Parrish had to accommodate Black parents' concerns about overly arduous scheduling. Their objections thus influenced the nature of industrial education at Eckstein Norton. But Parrish also had to accommodate the expectation of white Kentuckians that the institution maintain strict schedules. Like Armstrong, they expected African American students to adopt a subservient demeanor and methodical labor practices. Maintaining good relations with both the Black and white communities and ensuring the survival of the school thus required that Parrish perform a difficult curricular balancing act between industrial and academic training.

At Eckstein Norton University, Parrish established an exacting schedule that for over two decades balanced students' industrial workload with their academic study. As 
the Courier Journal noted in 1891, "The greater part of the practical work is done during the early hours of the day, the remainder of the time being devoted to recitations from text books. The entire system of the university is carried out in the same practical way." 11 The paper described in some detail the exacting daily routines of the students under Parrish's care: "The discipline of the school is very strict. . The pupils are required to be up by 6 o'clock, and by 7 every room must be in order. . Study hours are kept from 6 in the afternoon to 9 in the evening and by 9:30 every light is required to be out."12 As a white-owned publication, with a predominately white readership, the paper may have exaggerated accounts of the school's discipline and strict scheduling, but such reports suited Parrish's purpose, reassuring concerned whites and enabling him to retain control over the school's curriculum and administration. As a result, students at the Cane Spring school received a more balanced educational experience than their counterparts at Hampton and Tuskegee. Students at Eckstein Norton University certainly received industrial training, but they did not spend ten hours each day in physical labor. The considerable academic component of Eckstein Norton's curriculum reflected Parrish's commitment to the improvement of African American educational opportunities and the well-being of his students.

Evidence of the industrial approach at Eckstein Norton University, along with the material products and services it produced, appears in reporting about the school in the Louisville Courier Journal. The headline of a 1901 article, for example, stated, "Girls Trained to Cook, Sew and Do Housework and Boys Given Trades," adding, "The Higher and Elegant Branches of Study Not Neglected But Made Subsidiary."13 A year later, the newspaper published a report that included detailed illustrations of the dressmaking, 
carpentry, and various other departments, highlighting the industrial education and training students received. One image, labeled "Waiters Class," revealed white expectations of African American workplace subservience. ${ }^{14}$ Such reports accurately reflected the school's emphasis on industrial training and the range of courses it offered that prepared students for careers of manual labor.

\section{COVERTLY EMBRACING THE LIBERAL ARTS}

The Courier Journal's reporting did not, however, capture the broader educational aspirations of Parrish and the institution he administered. From the outset of their efforts, Simmons and Parrish conceived of the new school as a means to improve African American educational prospects in Kentucky. They did not seek to instill subservience into their African American students, nor did they view discrimination and Black secondclass citizenship as inevitable or natural. As Parrish's later writings from Golden Jubilee demonstrate, he firmly believed that racial equality for African Americans should and would be attained. "Human rights will be obtained," he declared, "even though the way lie through oppression." 15 Parrish's lifelong dedication to African American education and religion revealed that he viewed both strategies as crucial tools in achieving racial equality. Indeed, African American religious leaders in the South had served as community leaders and ambassadors to white communities since the end of the Civil War. DuBois identified Black ministers as crucial members of the southern African American community and described them as 'a leader, a politician, an orator, a 'boss,' an intriguer, and an idealist." 16 Thus, Parrish mirrored other religious leaders when he used religious rhetoric to resist white supremacy. But he remained an educator, and having successfully opened his school, he did not neglect his goal of improving African 
American education. School records, in contrast to the reports that appeared in the Courier Journal, reveal that he did not sacrifice traditional education for the industrial model. Rather, Parrish and his fellow faculty members concealed a traditional liberal arts education and a willingness to award advanced degrees behind a façade of industrialism.

Parrish could not emphasize traditional liberal arts courses and associated extracurriculars activities in school publications. Likewise, Eckstein Norton University's commencement ceremonies and faculty did not celebrate the advanced degrees the institution conferred because white opponents of Black schools, and even many sympathetic whites, opposed African American liberal arts education. In the words of Georgia Circuit Judge William Gary, reprinted in the Courier Journal in 1903, "negro schools are only ruining good plow hands in their efforts to fit negroes for places they are incapable of filling and which they will never be allowed to fill should they become capable." ${ }^{17}$ In the face of this white hostility, Parrish and his faculty publicly embraced industrial education while offering liberal arts courses clandestinely. Subterfuge proved necessary because the future of the school and the safety of students and staff depended on the goodwill of whites. Despite the risk, Parrish and his faculty offered advanced courses and awarded advanced degrees.

The school's course on cooking, for example, provided students with advanced training. On its surface, the course followed the industrial model, designed to prepare students for domestic or service industry labor. However, the course offered more than the basics of cooking. Students enrolled in the course received training in both chemistry and mechanics and learned how to create nutritionally sound meals based on doctors' recommendation. Ostensibly, this course prepared efficient chefs, but it contained a broad 
range of more advanced subjects and contemporary ideas about nutrition, which students disseminated throughout the African American community. ${ }^{18}$ Ironically, the Courier Journal published much of this specific information but did not challenge the advanced components of the course because the training of African American chefs reflected white ideals of Black servitude. In the face of white hostility and potential violence, Parrish and his staff used courses such as the cooking class to satisfy white expectations and offer indepth instruction to their students.

In this, Eckstein Norton diverged from the industrial curriculum at Hampton and Tuskegee, where some students objected to the perfunctory nature of courses in more advanced trades. Hampton Institute, for example, offered courses on printing, and shoemaking, among other trades, but students regularly complained about the quality of such courses. One student who entered the Hampton Institute to learn the printing trade was disappointed to find that he could not take the course, even though the school's newsletter, the Southern Workman, was printed on the campus. ${ }^{19}$ At Tuskegee, too, students had limited opportunities to learn more advanced trades. Both institutions strictly regimented their students' time and focused on manual labor and rudimentary academic education. Students lacked the time in their schedules and school administrators the inclination to offer advanced trade or academic courses.

Eckstein Norton University, in contrast, offered a wide range of advanced academic and artistic courses that offered in-depth training. Students in the Normal and Preparatory school could pick several of their courses, enabling them to customize their schedule and type of instruction. ${ }^{20}$ They could also choose to study in the printing, blacksmith, or carpentry shops. Student's ability to choose their own courses, and the 
school's dedication to providing strong instruction for these courses, differed markedly from the educational experience and curriculum offered at Hampton and Tuskegee. In another significant deviation from the traditional industrial model, Eckstein Norton placed more emphasis on the arts. The school offered regular and extracurricular courses on needlework, embroidery, and painting. For several years, students also obtained journalism, editing, and printing experience in the production of the student newspaper. Known as the Eckstein News and produced at the Cane Spring campus, the publication covered campus activities and significant events. Literary minded students and faculty, several of whom contributed to the Eckstein News, also organized a student organization known as the Advanced Literary Society. ${ }^{21}$ Such literary societies, commonly found within educated African American communities, served a variety of purposes. Not only did these organizations promote literary study, and thus provide a wider base of knowledge with which to navigate the segregated world, but they also refuted common white supremacist beliefs regarding African American intelligence. Through participation in literary societies, such as the one in Cane Spring, African Americans demonstrated a capacity for intellectual education and adaptation that contradicted racist ideologies and enabled them to resist white supremacy more readily. ${ }^{22}$

Students with more sophisticated ears could also choose music lessons offered by the musical conservatory. Directed by Ms. Hattie A Gibbs, an African American graduate of Oberlin College, the musical conservatory at Eckstein Norton University was the only such facility available to Black students in the South. As the Courier Journal recorded, "Only the highest branches of music are taught. The course of music is planned according to the methods used in the great Eastern conservatories. ${ }^{, 23}$ Extracurricular courses such 
as needlework and embroidery remained available only to women, but men who wished to pursue an artistic education had other options, such as the Eckstein Norton Brass Band. Students could learn to play a variety of instruments and often performed for distinguished and international audiences. Under the direction of R. R. Brown, the Eckstein Norton Brass Band played before United States Presidents Theodore Roosevelt and William H. Taft, and Mexican President José de la Cruz Porfirio Diaz. ${ }^{24}$ In contrast, neither Hampton nor Tuskegee offered formal musical training. The Courier Journal confirmed this unique aspect of the curriculum at Eckstein Norton, writing that "One of the great features of the University is the musical conservatory, the only colored one in the South."25

\section{STAGES OF EDUCATION}

Eckstein Norton also differed from Hampton and Tuskegee, as well as other institutes of higher education in Kentucky, in its willingness to offer education to younger children with little to no formal academic experience. Teaching students of all ages and abilities satisfied Parrish's fundamental educational goals while addressing the school's financial needs. The school's revenue stream consisted primarily of student tuition payments for industrial and traditional courses, supplemented by financial donations. The institution thus needed to recruit new students whose tuition payments enabled Eckstein Norton University to retain and enlarge the faculty and expand its instructional capabilities. Educating younger or inexperienced students, many of whom lived and studied at the Cane Spring location, increased the schools enrollments and tuition income. But the instruction of younger and uneducated students also expanded the educational opportunities of the African American community, Simmons and Parrish's central 
motivation for founding the school. Simply put, Black Kentuckians faced a variety of legislative and economic challenges in their efforts to obtain the most basic education. The enrollment of students with a broad range of abilities reflected Parrish's commitment to the improvement of African American education long after Simmons's death.

Eckstein Norton University admitted students with no prior educational experience to the Primary Department, in which the curriculum mirrored that of Kentucky's public schools. To meet the educational requirements of the Primary Department typically took four years, at which point the student received a primary certification and was eligible to enroll in more intellectually strenuous courses. ${ }^{26}$ Students could then transition to the next stage of their education in the Training Department. This course of study took two years and resembled the curriculum of a public middle school, with the first year corresponding to the sixth grade, and the second year to the seventh and eighth grades. After receiving certification from the Training Department, students could then choose to focus on industrial courses or continue pursuing a traditional education. $^{27}$

The third phase of traditional education at Eckstein Norton University was known as the Normal and Preparatory Department. At this stage, students selected their own course of study, with the expectation that they choose coursework most relevant to their future careers. Students could also take secondary courses that, while not necessarily leading to a specific career, provided a more well-rounded education. Students who graduated from the Normal and Preparatory Department, usually after four years of study, held the equivalent of a normal or high school education. Most students who graduated from Eckstein Norton University earned a normal degree and with it they could become 
teachers themselves. ${ }^{28}$ Successfully educating future Black teachers who could address the shortage of qualified African American educators in the state represented a significant achievement for a school dedicated to expanding Black educational opportunities. ${ }^{29}$ In the College Department, the fourth and final level of education at Cane Spring, students could choose their own course of study in either the arts or the sciences; their selections determined whether they received the degree of Bachelor of Arts or Science. Students took a final examination at the end of their coursework, at which point they received their college diploma. ${ }^{30}$

\section{THE GRADUATES}

The variety of educational options available to students at Eckstein Norton University belies the description of the school found in contemporary white publications. The school offered industrial courses and many students graduated with certificates in various industrial trades, but traditional liberal arts subjects absorbed a large part of the time of both students and faculty. Indeed, graduation records from the Eckstein Norton Catalog reveal that the majority of the school's graduates earned a traditional liberal arts degree. Between 1892 and 1911, 105 students graduated from the Normal and Preparatory Department. During the same years, ten students received a bachelor's degree in either the arts or sciences from the College Department. In contrast, only seventy-four students received certificates in in some sort of trade, and the Dressmaking Department awarded fifty-one of these certificates. ${ }^{31}$ Altogether, 61 percent of the degrees and certificates awarded at Eckstein Norton University came through the Normal and College Departments. While the white Kentuckians who sponsored and reported on the school praised its industrial focus, Parrish and his faculty quietly trained over one hundred 
potential teachers to improve African American educational prospects in Kentucky. And the school accomplished this feat without consistent financial support from the state and despite the opposition of most white Kentuckians to Black education.

\section{FINANCIAL CONSIDERATIONS: FUNDRAISING AND TUITION}

Financial pressures persistently shaped the actions of Parrish and his staff, all of whom knew that Eckstein Norton University would fail without a constant influx of new capital. Eckstein Norton and his family continued to sponsor the school, but Parrish's fundraising decisions demonstrate that his acute awareness of the financial needs of the institution. ${ }^{32}$ In particular, Parrish turned to the same networks of sympathetic white elites who offered support to Hampton and Tuskegee. ${ }^{33}$ Unlike Washington, Parrish could not regularly travel north to raise money because of his responsibilities as both school administrator and religious minister. Instead, he sent the students themselves on fundraising expeditions. Most often, he employed the Eckstein Norton Brass Band in this capacity, and as both fundraiser and publicity agents the band enjoyed considerable success. The band performed in front of many diverse and illustrious audiences and continued to do so until the school closed. ${ }^{34}$ In 1909, for example, the band played one of its most memorable performances before President Theodore Roosevelt at the laying of the memorial cornerstone at Abraham Lincoln's Kentucky birthplace. ${ }^{35}$

The singularity and talent of the Eckstein Norton Brass Band made them an important fundraising tool of the school. But Parrish and his staff utilized other methods, including a quartet of singers trained in the musical observatory at Cane Spring who regularly traveled throughout the southern and western states. As a result of the singers' efforts, the school enjoyed an increase in enrollment from the Pacific coast. ${ }^{36}$ When he 
could spare time from his other duties, Parrish undertook short fundraising expeditions. His academic and religious credentials and experience in Kentucky made him well suited for these regional fundraising expeditions. In 1891, for example, Parrish traveled the state seeking funds to establish a shoemaking and machine shop. As the Louisville Courier Journal reported, "There are several branches which are to be added to the curriculum during the coming holidays. . . The sum of $\$ 4,000$ is necessary to start this work. . President C.H. Parrish will make a tour of the State with four soloists in the hope of raising this amount." 37

Parrish recognized that his institution's distinctive features attracted the interest of white elites and could benefit the institution financially. In this regard, Parrish's fundraising strategies mimicked those of the other African American schools of the time period, whether they embraced a liberal arts or industrial approach to education. Washington, for example, undertook extended lecture tours, drawing on his fame and oratorical skills to gain the favor and financial support of white elites. Parrish lacked the national prestige of Washington and thus turned to the school's unique musical program to attract white interest and patronage. The Eckstein Norton Brass Band served a similar role to that of the Fisk University Jubilee Singers, who functioned as representatives for the Nashville-based African American university and sang for both American elites such as United States President Ulysses S. Grant and wealthy Europeans. Traveling around the world, the Jubilee Singers ultimately raised one hundred fifty thousand dollars for their institution. ${ }^{38}$ The Eckstein Norton Brass Band never attained this level of fame but they nonetheless served as the school's ambassadors to the wider world, drawing national attention, financial donations, and additional students to Eckstein Norton University 
Students' tuition payments and fees represented a second relatively stable source of revenue for the school. Since emancipation, students and their families had supported independent African American schools. Indeed, the first Black school administrators depended on student tuition to keep their schools in operation because southern state legislatures provided no support for African American schools. ${ }^{39}$ Also lacking state support, Parrish likewise depended on the tuition and housing fees of his students. Without continuing full enrollment Eckstein Norton University's doors would close. Accordingly, the school kept a personalized record of each student's charges and payments. Student expenses typically fell into two categories, those charged by the month and those charged by the semester or as needed. Monthly charges included room and board, tuition, and class fees. Occasional charges, either by the semester or as necessary, included a fee for the use of industrial facilities, vaccination, and items of clothing. ${ }^{40}$

Student Expenses and Fees at Eckstein Norton University 1893-1894

Monthly Expenses

Room \& Board $\$ 6$

Washing

Tuition

Dressmaking

Music

$\$ 1$

$\$ 2$

$\$ 3.60$
Occasional Expenses

Industrial $\mathrm{Fee}^{*} \quad \$ 2.50$

Shoes $\quad \$ 1.50$ to $\$ 1.98$

Hat $\$ 0.50$

Vaccination* $\$ \$ 0.50$

Baggage Handling $\$ 0.20$

*Semesterly Expenses

Of the monthly charges, room and board represented the most significant expense for the student. Participation in the music and dressmaking courses, both of which 
required extensive equipment, materials, and training, also required a significant investment of the student. However, expenses incurred for such courses were justified by the potential employment opportunities available to the student after graduation, whether in the garment or the music industry. Monthly tuition expenses, equivalent to monthly laundry fees, remained relatively low but did not include the fees attached to various traditional or industrial courses. Other occasional expenses, including vaccination, baggage handling, and items of clothing, reflected the immediate needs of the students and the capabilities of the staff. ${ }^{41}$ Many students entered the school without adequate healthcare or appropriate clothing, requiring administrators and staff to provide for the needs of these new arrivals. School staff also arranged for the safe transportation of the possessions of new and returning students with large amounts of baggage. All expenses, whether repetitive or intermittent, were noted by the school and applied to the student's outstanding debt.

In 1893, Eckstein Norton University had ninety-two students, all of whom paid a monthly tuition charge. Thus, even in the absence of room, board, and other fees, tuition charges represented a significant source of income for the university. This revenue stream required steady enrollment, making the school dependent on its good reputation within the African American community. Fortunately, Black Kentuckians had a high regard for Parrish, if not the school itself. Nonetheless, dependence on continued high enrollment and the Black community made the school susceptible to changes in the state and national economy. Indeed, periods of high unemployment and national recession that affected the African American community, had an adverse effect on the financial viability of Eckstein Norton University. The financial panics of the 1890s, reaching crisis levels in 1893 and 
1896, had a significant impact on the institution. Sparked by overly-expansive business growth, a profusion of badly-considered loans, and other inflationary economic measures, the economy of the United States experienced volatile shifts in the 1890s. ${ }^{42}$ The African American community suffered during these economic crises as industrial businesses, a common source of Black employment, did less business and offered fewer working hours. ${ }^{43}$ As a result, enrollment decreased, leaving the school without much needed tuition payments. The white elites who supported Eckstein Norton also suffered, leading to fewer donations to the school.

\section{THE IMPORTANCE OF COMMUNITY SUPPORT}

Notwithstanding periodic economic downturns, student payments and financial donations from white elites did much to alleviate the financial strains at Eckstein Norton University. Still, the school never attracted the level of funding or the northern philanthropic connections enjoyed by larger and more well-known institutions like Tuskegee. When white philanthropy provided inadequate assistance, Parrish and his staff depended on the goodwill of the Black community. Parrish's close relationship with the African American Baptist Church, in which he continued to minister after assuming the presidency of Eckstein Norton, encouraged that religious community to contribute to the institution. Parrish's church, Calvary Baptist, often supplied clothing and resources to the faculty and students. As local historian Lee L. Brown noted, "A sketch of the school would be incomplete without saying a word in reference to Calvary Baptist Church... The staunch friendship existing between the Church and the school is well-known. For many years a committee of members have come to the school bringing their baskets filled with good things for the teachers and students. Also, the same committee would serve lunch at 
commencement time after the exercises at the theatre. ${ }^{" 44}$ Facing mounting economic concerns after the sudden death of Simmons in 1890, Eckstein Norton University held its first annual commencement ceremony at the nearby Fifth Street Baptist Church. ${ }^{45}$ In later years, local Black religious and community organizations like the Prince Hall Masons offered their facilities to the school and often hosted significant school events such as graduation ceremonies. ${ }^{46}$ Holding school events away off campus increased the Black community's investment in the institution, raising the likelihood of financial and other types of aid. It also heightened the public profile of the institution, a form of advertising that encouraged local African Americans to enroll at Eckstein Norton.

Parrish and his faculty also used such public events to interact with and assuage the fears of the white community in Kentucky. Parrish regularly invited influential white community leaders to campus events such as commencement ceremonies and the annual Donor's Day to reassure them that the school represented no challenge to the racial status quo and perhaps secure their support. Cultivating white allies in this fashion proved essential when the school faced financial emergencies, including when the main building burned down in the early 1890s. As Brown noted, "The white friends in the immediate neighborhood of the school have been courteous, ever ready to lend a helping hand. At commencement time they have come in great crowds and have shown their appreciation by hearty applause... At the time of the burning of the main building, they came to the rescue of Dr. Parrish, by making large contributions. ${ }^{~} 47$ The Louisville Courier Journal regularly reported these school events, including the May 25, 1905 commencement ceremonies, in a positive light, revealing the success of Parrish's efforts to garner the approval of the surrounding white population. ${ }^{48}$ 
School ceremonies helped build stronger relationships between Eckstein Norton and the surrounding Black and white communities, but they also represented significant milestones in the school schedule. These events were much anticipated celebrations and both students and staff built their schedules around them. The commencement exercises combined public exhibition, talent show, and the graduation ceremony. Students in the musical conservatory and the members of the Eckstein Norton Brass Band performed for the audience. Well-known guest speakers rounded out the program, enhancing the prestige of the school and the occasion. ${ }^{49}$ Guest speakers were usually prominent African Americans, such as the medical doctor and Minister Evans Tyree, who spoke at the commencement ceremony in $1895 .{ }^{50}$ Each ceremony closed with Parrish presenting the new graduates and distributing the appropriate certificates and diplomas. As the Courier Journal reported in 1895: "The commencement exercises of this university for colored students began Monday with field day on the university grounds at Cane Spring... Tuesday there was the reunion of students... The training school and graduates in industries furnished the features for Wednesday, and Thursday was devoted to the general conference, conservatory of music and the English graduates."

The annual Donor's Day was an equally significant event for the school and its supporters. First held on December 16, 1893, the birthday of the school's chief patron Eckstein Norton, the event became a way to commemorate Norton and other patrons. The Courier Journal described the first Donor's Day in 1893:

"The Eckstein Norton University, at Cane Spring, twenty-nine miles from Louisville, yesterday celebrated the birthday of the late Eckstein Norton. . Next came a 'Eulogy' of Mr. Norton, delivered by the Rev. C. H. Parrish, President of 
the university. Dr. Parrish gave a short, but interesting sketch of Mr. Norton's life, and spoke feelingly of how much he had done in the establishment of the university for the cause of colored education. The exercises closed with the singing of a memorial ode, 'Our Own Eckstein,' composed by Dr. Parrish and set to music by Prof. Hattie Gibbs." ${ }^{.52}$

School ceremonies, such as commencements and Donor's Days, became a large part of life at Eckstein Norton University. The school used these social events to unite their school community and build bridges to the surrounding African American and white communities.

The regularity of these ceremonies demonstrated the administrative and fundraising success of the school, as did the dramatic changes taking place on the Cane Spring campus. Under Parrish's firm leadership and commitment, the school and its facilities constantly improved and expanded. When the main building of the school burned down in 1892, Parrish immediately began raising funds to finance the construction of a new structure. He issued an appeal through the Courier Journal, writing, "We therefore appeal to you as an institution of vigorous vitality, whose influence is already felt in preparing the youth for intelligent citizenship." ${ }^{\prime 53}$ After several months of fundraising, which included national appeals, the school had enough money to erect a new building. ${ }^{54}$ In subsequent years, Parrish continued to expand the Cane Spring campus. In 1904, a new chapel was raised and dedicated on Thanksgiving. ${ }^{55}$ Three years later, in 1907, the Board of Trustees agreed to fund an expansion in the school's science department in the areas of agriculture and domestic science. ${ }^{56}$ Under Parrish's leadership, the Eckstein Norton campus continued to grow, as did the number of students enrolled at 
the university. The school opened in 1890 with only fifty-two students. By 1895, seventyfour students enrolled in the school. Six years later, the school counted ninety-seven students and by 1908 the student body reached 117 , more than double the original enrollment. In the face of numerous challenges, Eckstein Norton University had grown considerably, increasing both the range of classes and the number of students.

Simmons's untimely death, only weeks after the school's opening, had a profound impact on Parrish and the Cane Spring campus. The new school had lost its greatest champion and most experienced administrator. But Parrish and his faculty rose to the challenge. They likewise surmounted the economic and social obstacles they faced in the years that followed. The school employed a variety of methods to ensure its financial stability and improve African American educational opportunities. Like other African American schools, Eckstein Norton University's teachers and students traveled the state and country, using their connections and artistic talent to raise funds and promote the school. Parrish also adopted novel strategies not employed by other industrial school, most notably offering admission to younger and inexperienced students. The school worked persistently to expand its community engagement and build a base of Black and white support. Under Parrish's steady leadership, the school secured a financial base and expanded its curriculum. Operating at the edge of white awareness and always careful to assuage white concerns, the school offered both traditional liberal arts and industrial training. Hundreds of students graduated, over half of whom had the potential to become educators. In the twenty years after 1890, Eckstein Norton University, once Simmons and Parrish's dream, grew into a bustling and productive institution that expanded the educational opportunities of Black Kentuckians. 
1 “Eckstein Norton University,” 1911, Eckstein Norton File, Bullitt County Historical Society, Shepherdsville, Kentucky (hereafter BCHS).

2 'Louisville, Kentucky. Seasonal Average Temperatures, Total Precipitation, and Total Snowfall.” The National Weather Service.

https://www.weather.gov/media//mk/climate/clisdf/seasonal_av_temp_total_precip_total _snow.pdf (accessed Feb. 23, 2021).

3 “Enrollment of Eckstein Norton University," 1911, Eckstein Norton File, BCHS.

${ }^{4}$ Ibid.

5 “Taught to Work: Eckstein Norton University's Departure in Colored Education, Girls Trained to Cook, Sew, and Do Housework and Boys Given Trades the Higher and Elegant Branches of Study Not Neglected but Made Subsidiary, Remarkable Success of an Institution Founded by Mr. Eckstein Norton and Others, Commencement Exercises Yesterday," Courier-Journal, June 18, 1891.

6 "Description of Courses," 1911, Eckstein Norton File, BCHS.

7 “Taught to Work," Courier-Journal, June 18, 1891.

8 "Description of Courses," 1911, Eckstein Norton File, BCHS.

9 “Taught to Work," Courier-Journal, June 18, 1891.

${ }^{10}$ Booker T. Washington, Up From Slavery (New York: Doubleday, 1901), 51.

11 “Taught to Work," Courier-Journal, June 18, 1891.

${ }^{12}$ Ibid, 108.

${ }^{13}$ Ibid.

14 “A Kentucky Tuskegee: Good Work Done at the Eckstein Norton School," Courier Journal, May 18, 1902. 
${ }^{15}$ C. H. Parrish, Golden Jubilee of the General Association of Colored Baptists in Kentucky: The Story of 50 Years' Work from 1865-1915 Including Many Photos and Sketches, Compiled from Unpublished Manuscripts and Other Sources (Louisville: Mayes Print, 1915), 29.

${ }^{16}$ Edward Ayers, The Promise of the New South: Life after Reconstruction (New York: Oxford University Press, 1992), 164.

${ }^{17}$ Negro Schools Ruining Good Plow Hands: Georgia Judge's Declaration to the Grand Jury_-Urges a Change in System of Taxation for Education of Colored Race, CourierJournal, October 20, 1903.

18 “Taught to Work," Courier-Journal, June 18, 1891.

${ }^{19}$ James D. Anderson, The Education of Blacks in the South, 1860-1935 (Chapel Hill: University of North Carolina Press, 1988), 58.

20 “Description of Courses," 1911, Eckstein Norton File, BCHS.

${ }^{21}$ Lee L. Brown, "A Short History of Eckstein Norton,” 1911, Eckstein Norton File, BCHS.

${ }^{22}$ Hilary Green, Educational Reconstruction: African American Schools in the Urban South, 1865-1890. (New York: Fordham University Press, 2016), 79, 80.

23 “Taught to Work," Courier Journal, June 18, 1891.

${ }^{24}$ Brown, "Short History of Eckstein Norton", Eckstein Norton File, BCHS.

25 “Taught to Work," Courier Journal, June 18, 1891.

26 "Descriptions of Courses," 1911, Eckstein Norton File, BCHS.

${ }^{27}$ Ibid.

${ }^{28}$ Ibid. 
29 "Graduates of Eckstein Norton, 1892-1911,” Eckstein Norton File, BCHS.

30 "Descriptions of Courses," 1911, Eckstein Norton File, BCHS.

31 “Graduates of Eckstein Norton, 1892-1911,” Eckstein Norton File, BCHS.

${ }^{32}$ Brown, "Short History of Eckstein Norton," Eckstein Norton File, BCHS.

${ }^{33}$ Washington, Up From Slavery, 125.

${ }^{34}$ Brown, "Short History of Eckstein Norton," Eckstein Norton File, BCHS.

${ }^{35}$ Courier-Journal, September 17, 2000.

${ }^{36}$ Brown, "Short History of Eckstein Norton," Eckstein Norton File, BCHS.

37 “Taught to Work," Courier-Journal, June 18, 1891.

${ }^{38}$ C. Robert Tipton, "The Fisk Jubilee Singers." Tennessee Historical Quarterly 29, no. 1 (1970): 42-48.

${ }^{39}$ Green, Educational Reconstruction, 23.

40 “Boarding School Ledger," 1893-1894, Eckstein Norton File, BCHS.

${ }^{41}$ Ibid.

${ }^{42}$ Alexander D. Noyes, "The Banks and the Panic of 1893." Political Science Quarterly 9, no. 1 (1894): 12-30.

${ }^{43}$ Ibid,, 13.

${ }^{44}$ Brown, "Short History of Eckstein Norton," Eckstein Norton File, BCHS.

${ }^{45}$ Ibid.

46 “Eckstein Norton,” Courier-Journal, June 14, 1895.

${ }^{47}$ Brown, "Short History of Eckstein Norton,” Eckstein Norton File, BCHS.

48 “Commencement of Eckstein Norton Institute," Courier-Journal, May 25, 1905.

49 “Eckstein Norton," Courier-Journal, June 14, 1895. 
${ }^{50}$ Ibid.

51 Ibid.

52 “Eckstein Norton Day,” Courier-Journal, December 17, 1893.

53 “An Appeal for Aid: The Faculty and Directors of Eckstein Norton University Ask for Help toward Rebuilding," Courier-Journal, January 27, 1892.

${ }^{54}$ Brown, "Short History of Eckstein Norton,” Eckstein Norton File, BCHS.

55 “Dedication of a New Chapel,” Courier-Journal, November, 20, 1904.

56 “Increased Facilities for Teaching Science,” Courier-Journal, May 12, 1907. 


\section{CONCLUSION}

African American education in Kentucky faced many challenges after the end of the Civil War. Immediately following the war, the Kentucky state legislature outlawed interracial education in public schools, making it illegal for Blacks and whites to attend public schools together. Although both communities paid educational taxes, the separation of the races made it possible for the legislature to divert educational funds to white schools before they reached African American schools. ${ }^{1}$ In addition to discriminatory funding practices, African American schools suffered from a shortage of educated professionals. Thus, even when Black Kentuckians established and obtained funding for their schools, a lack of teachers hindered their ability to educate their students. Northern philanthropies, more concerned with sending assistance to the Deep South, offered little assistance.

Concerned Black Kentuckians realized that neither northern nor southern whites would provide substantive support for African American schools. The responsibility for obtaining more educational opportunities and securing more government support instead fell to the Black community. Most notably, the Kentucky General Association of Colored Baptists brought together the religious and educational communities and created the Kentucky Normal and Theological Institute, later renamed State Colored Baptist University or State University. William J. Simmons led the school from 1880 to 1890 , amalgamating smaller educational institutions with State University and training educators to fill empty teaching posts. Simmons also found a mentee in Charles H. Parrish, who attended and then worked at State University. Both men achieved 
considerable success at the State University, but African American schools required additional teachers. ${ }^{2}$ Familiar with the needs of their community and conscious of the growing popularity of the industrial model, Simmons and Parrish sought to create a new industrial school. This thesis argues that Simmons and Parrish's use of the industrial model reflected their belief that improving African American educational opportunities required cooperation with elite whites. Their use of the industrial model enabled them to obtain additional white financial support and administer the school without direct white interference. This autonomy also permitted them to offer instruction in the liberal arts, a practice that otherwise would have sparked white resistance. In short, Simmons and Parrish used the tools and strategies available to them in order to improve educational opportunities for Black Kentuckians.

The two men garnered support from wealthy white elites like Eckstein Norton and established the university named after him in 1890. Despite Simmons death weeks after the school opened, Parrish established a successful institution. Over one hundred teachers trained at Eckstein Norton went on to serve their communities. These educated Black men and women learned valuable skills that enriched their communities and better prepared them to resist white supremacy. ${ }^{3}$ The actions and accomplishments of Eckstein Norton University alumni both validated the efforts of the school's administrators and supporters and illustrated the far-reaching impact of the institution.

\section{THE ALUMNI OF ECKSTEIN NORTON UNIVERSITY}

The alumni of Eckstein Norton pursued a variety of careers and occupations. Graduates of the dress making department, many of whom had invested considerable time and capital in their course of study, often worked in the garment and textile industry. Students 
trained in the industrial education departments followed a variety of careers, their skillset supplemented by the liberal arts educational courses received at the school. Many graduates of the normal school became public school teachers, helping to alleviate the shortage of African American teachers in Kentucky. For most of these men and women, the time at Eckstein Norton University started a lifelong journey of learning and teaching. As teachers and activists, they also helped to develop additional educational opportunities for African Americans. P.T. Frazer, for example, worked as a college professor, before becoming president of the Hopkinsville, Kentucky, Male and Female College. ${ }^{4}$

The careers of many graduates of the Cane Spring school remain unknown, but their service as educators and further contributions to African American education was apparent in their regular association with and support of their alma mater after graduation. ${ }^{5}$ Alumni regularly attended commencement exercises and other important school holidays, and the most prominent among them delivered speeches to students and school supporters. ${ }^{6}$ The alumni and the speeches they offered served multiple purposes. They inspired both current and prospective students and their parents, but they also reminded supporters of the school's success. To a donor or potential donor, the presence of well-spoken and successful school alumni offered proof that Eckstein Norton University was fulfilling its mission. Graduates of the school also maintained an active alumni association that met regularly. ${ }^{7}$ Through this organization and involvement with the school community, alumni supported and celebrated the school and the contributions of Parrish and his staff. The encouragement and endorsement of the Eckstein Norton alumni support network became increasingly important as the university entered its second decade of operation. 


\section{CHALLENGES CONTINUE}

Despite the school's many successes, the obstacles facing Parrish and staff remained formidable. Like all African American educators in Kentucky, Parrish depended on the patronage and goodwill of elite whites. The backing of Eckstein Norton and the L\&N Railroad had proven essential in the creation and opening of the school. Unfortunately, on January 12, 1893, the institution's largest benefactor and namesake passed away. Norton's last will and testament, detailed in the Louisville Courier Journal, demonstrated the immense wealth he had accumulated over his business career. He left two hundred fifty thousand dollars to his wife and thirty-five thousand dollars to each of his five children, held in trust until they reached maturity. The will also briefly mentioned two African American servants, Sally and Sadie, who each received five hundred dollars. ${ }^{8}$ Surprisingly, Norton's will left no funds to the school that bore his name. Nevertheless, his family remained concerned for the welfare of the institution. His son, George W. Norton, demonstrated a continuing interest in the school and may have contributed to its rebuilding after the fire of $1892 .{ }^{9}$ According to the Courier-Journal, Eckstein Norton Jr. visited the school in December 16, 1896, the day of "his father's birthday," "expressed himself as being deeply interested [in the school], and said that his mother and sister desired to contribute to the success of the institution." ${ }^{10}$ The Norton family's continuing support for the school no doubt heartened Parrish, but their interest and influence could not protect the school from the challenges the new century would bring.

Most important, the school was affected by the Kentucky state legislator's shifting approach to the subject of African American education. Though Eckstein Norton University never received direct state support, the decisions of white politicians impacted 
the welfare and future of the school. Since 1890, the Kentucky state legislature had shown reluctance to expand its miserly support for African American schools. In 1908, for example, Parrish unsuccessfully applied for a three thousand dollar grant from the state government. The refusal of the state to support Eckstein Norton University in part reflected the assembly's decision to continue its support, however meager, for Kentucky State, and to provide funds for the creation of a new industrial institution in western Kentucky. Ironically, while Parrish and Simmons had worked at State University in Louisville in the mid-1880s, they had lobbied for the creation of Kentucky State. After 1902, however, Kentucky State adopted a more industrial approach in its curriculum, putting it in competition with Eckstein Norton University for the same students and potential supporters. ${ }^{11}$ The school Parrish and Simmons once supported now posed a threat to Eckstein Norton's survival. The creation of the Paducah-based Western Kentucky Industrial College for Colored Persons in 1909 posed a similar challenge. Established by D. H. Anderson, the new school met the pressing need for Black educational opportunities in the western part of the state. Dedicated to the industrial model, Anderson lobbied the state legislature for support and eventually won an annual appropriation of three thousand dollars for the western school. ${ }^{12}$

But the biggest challenge to Eckstein Norton University came as a result of the 1904 Day Law, outlawing interracial education in private institutions. The legislation specifically targeted Berea College, which after the passage of the law became an allwhite institution. While white politicians like the law's architect Carl Day celebrated the segregation of private institutions, African American educators and activists lobbied against the law's passage in the both the legislature and the court system. Despite their 
efforts, the Day Law remained and Berea's tenure as an interracial institution ended. ${ }^{13}$ In response, Black educators planned a new school to cater to African Americans and provide the educational opportunities that Berea College could no longer offer. Though the African American community debated the curriculum of the new school they ultimately reached the same conclusion as Simmons and Parrish in 1890. In the face of segregation, violence, and discrimination, and with the state legislature opposed to liberal arts training for African Americans, the promoters of the new school adopted the industrial model. Booker T. Washington, the leading spokesperson of the industrial model, directly supported the new private institution, named the Lincoln Institute, and located twenty miles east of Louisville in Simpsonville. ${ }^{14}$

\section{THE LINCOLN INSTITUTE}

Though supported by many prominent African Americans and elite whites, Shelby County representative John Holland tried to halt the school in 1910 by sponsoring a law that required a three-fourths assembly vote on the location of new industrial schools. As the Courier-Journal noted, "House bill 347, introduced by John W. Holland, of Shelby County, providing for the regulation of the establishment of industrial schools. . . was passed by a vote of 63 to 7." "15 Two months previously, Holland had sought the repeal of the 1908 Sullivan school law, which increased taxation to create new schools and fund those already in existence; it also established county boards of education that decided educational budgets and had the power to consolidate schools. ${ }^{16}$ Holland did not protest the increase in taxation or the creation of school boards, but he worried that African Americans might serve on the boards of trustees of white schools. Holland's actions reveal the ongoing hostility of white legislators to African American education. ${ }^{17}$ 
However, the Kentucky Court of Appeals ultimately sided with the friends and allies of the Lincoln Institute and declared Holland's law unconstitutional. Angry local whites issued further threats, but Lincoln Institute found a home in Simpsonville. ${ }^{18}$

Work on the new school progressed quickly, posing a serious challenge to Parrish and his school. The Lincoln Institute was located ten miles closer to Louisville and its educational approach mirrored that of Eckstein Norton. A. Eugene Thomson, an educator and minister, served as the school's first president. His experience as an educational and religious leader mirrored Parrish's career, with whom he would later work. Like Eckstein Norton University, the Lincoln Institute's curriculum consisted of both industrial and liberal arts courses. Agricultural instruction took place on a four-hundred-acre farm, which school administrators expected to be productive and profitable. ${ }^{19}$ The school also offered courses in carpentry, blacksmithing, and other industrial pursuits. Although the school offered liberal arts courses and operated a normal school for the training of teachers, administrators and sponsors emphasized the industrial model. ${ }^{20}$ Before the opening of the school, Thomson visited Hampton and Tuskegee to learn and emulate more fully the methods of those schools. These trips also reassured white critics around the state who worried about the creation of a new African American school. As the Courier-Journal reported, Thomson visited "most of the greater colored schools of the South, and understands the principles of the work thoroughly.",21

In their use of the industrial model and efforts to appease white Kentuckians, Eckstein Norton University and the new school paralleled each other. As a result, both private schools competed for the same resources, faculty, and students. ${ }^{22}$ Parrish may have welcomed the increased educational opportunities provided by the new industrial 
schools in Kentucky, but the growing competition had disastrous consequences for his own institution. Declining enrollments and financial support convinced Parrish to close Eckstein Norton University in 1912. Still, the school did not cease operations entirely. Just as State University under Simmons's direction had amalgamated with several smaller African American schools, the new Lincoln Institute absorbed Eckstein Norton. Discussions about the consolidation of the two schools started in 1909, when white trustees of Eckstein Norton, including George W. Norton, began to express concern about the financial stability of the school. After meeting with the president of Berea College, William Goodell Frost, the boards of both institutions reached a consensus. The Lexington Herald-Leader described their decision:

"It was felt that if one, big efficient school for the industrial and normal training of Negroes could be established to take the place of Eckstein-Norton, which, on account of lack of funds, has been somewhat hampered in its work, it would be better all around. . The merger of the two, therefore, is entirely one of harmony, and [in] the Lincoln Institute will [be] realized the aims of those who have been fostering Eckstein Norton."23

Leaders of the two institutions ensured the current students of Eckstein would be welcomed at the new school, although how many of the students made the transition is unclear. ${ }^{24}$ Aside from Parish, who served on the board of the Lincoln Institute, the faculty and staff of Eckstein Norton were not employed by the new school. ${ }^{25}$ In fact, the Lincoln Institute tended to hire white educators, a practice markedly different than that employed at Tuskegee and Eckstein Norton. A 1916 United States Bureau of Education report stated that eight of the fifteen teachers at the Lincoln Institute were white. ${ }^{26}$ Such hiring 
practices did not bode well for the faculty and staff at Cane Spring, who lost both their jobs and home. After twenty-two years of operation, the school that Simmons and Parrish had built together closed its doors for the final time. Still, the school left a potent legacy. During its period of operation, the school offered a valuable education to over fifteen hundred students and awarded almost two hundred degrees. ${ }^{27}$

\section{PARRISH'S WORK CONTINUES}

After leaving Eckstein Norton in 1912, Parrish continued to work for the improvement of African American education. He served on the board of the new Lincoln Institute and remained the pastor of Calvary Baptist Church. ${ }^{28}$ In 1918, he followed the footsteps of his former mentor Simmons and served as the president of State University. ${ }^{29}$ Under his administration, State University solidified its curriculum, offering a range of industrial, theological, and traditional liberal arts courses. However, Parrish still depended on elite white social and financial support. Knowing that unique institutional characteristics encouraged financial donations, Parrish used fundraising methods similar to those he employed at Eckstein Norton University. Most notably, he encouraged the use of the school choir, which performed concerts and appeared on early radio stations. Serving the same function as the Eckstein Norton Brass Band, the student musicians raised funds and attracted new students to the school. Although he continued to face financial adversity and resistance from white legislators, Parrish proved once again an able administrator. Importantly, he never stopped encouraging educational and religious growth within the African American community. Reflecting his lifetime commitment to the principles of Black educational and moral improvement he had learned from his mentor, he also oversaw the renaming of State University to Simmons University, forever associating 
Simmons's name with the education of Black Kentuckians. ${ }^{30}$ Parrish served as the president of Simmons University until his death on April 8, 1931. His son, Charles H. Parrish Jr., born in 1899 during his father's tenure at Eckstein Norton University, became the first Black faculty member at the University of Louisville in $1951 .{ }^{31}$

\section{AFRICAN AMERICAN EDUCATION AFTER 1912}

Though Eckstein Norton University closed in 1912, the industrial model of education that Simmons and Parrish adopted continued at other Black institutions in the state, including Lincoln, Kentucky State, and Western Kentucky Industrial College. In the 1910s and 1920s, Black educators continued to find advantages in the industrial model, not the least of which was the willingness of whites to accept and patronize the approach. The support of both the state legislature and the general public reflected white Kentuckians' assumption that industrial education prepared African Americans for menial and lowpaying jobs. The industrial model continued to enjoy white support, and African Americans continued to suffer from unequal educational opportunities, until these jobs became unnecessary or valued by whites. Indeed, not until the onset of the Great Depression would whites reconsider the industrial model.

The economic collapse that followed the stock market crash of 1929 brought important changes to employment and education in Kentucky. With rising unemployment white workers eagerly competed for traditionally African American jobs, creating a job crisis for Black Kentuckians. Historian James D. Anderson identifies this change as a form of economic displacement, when traditionally "Negro jobs" became "white jobs." 32 The increasingly competitive job market destroyed traditional conceptions of Black and white jobs and made the objectives of industrial education less relevant. Collusion 
between white workers and employers excluded African Americans from jobs traditionally open to them. Such racist employment practices made industrial training irrelevant because it no longer offered an economic advantage to students. ${ }^{33}$ In response, African American schools reconsidered the industrial model. Black educators and activists, recognizing that the industrial model no longer benefited African American students, campaigned to restore a traditional liberal arts curricula in their schools. The struggle to upend industrial education would continue for several years, but the 1930 opening of the Louisville Municipal College for Negroes, a liberal arts college associated with the University of Louisville, revealed its loss of support in Kentucky. ${ }^{34}$

\section{A FINAL SUMMARY}

After Reconstruction, Black southerners struggled to secure educational opportunities. In Kentucky, African Americans faced discrimination, broad inequalities, and the threat of racial violence. Even after the state government decided to support public schools, Black education suffered from a lack of funding and a dearth of qualified instructors, though a small number of African Americans earned college degrees. Born a slave in Kentucky, Parrish gained his education at State University, where he also found a mentor in Simmons. Together, Simmons and Parrish worked to improve African American education in the state. Not satisfied with their work at State University, the men decided to start another school. Knowledgeable about Kentucky's educational system and cognizant of their need for white support, they decided to open an industrial school on the model of Washington's Tuskegee. They found an ally in the L\&N Railroad and named their school after its president and their largest donor. Thus, Eckstein Norton University came into existence. 
Simmons died suddenly only weeks after the school opened, but Parrish stepped forward and led the school for over two decades. Under Parrish's guidance, the school taught both industrial and traditional liberal arts courses, although the industrial aspect of the coursework remained the primary focus of white supporters. Notably, the twelve students who received college degrees from Eckstein Norton University garnered little white attention, evidence that Parrish and his staff capably navigated the racialized environment in which they lived and worked. Through hardship and struggle, including the destruction of the main building only two years after the school's opening, Parrish and his staff persevered. They utilized a variety of methods, some traditional and others unorthodox, to sustain the school. The Eckstein Norton Brass Band and other members of the musical courses traveled the country, fundraising and advertising for the school. Parrish opened the school to students of all ages and abilities, making it easier for African Americans to receive an education and widening his pool of potential students.

Some members of the African American community frowned on the school's public embrace of the industrial model, but Simmons and Parrish adapted Washington's flawed model of education to promote their long-term goal of expanding African American education. The legacy of both men as successful educators thus looms large in the history of Kentucky. Simmons and Parrish saw a pressing need - the lack of Black educational opportunities and educators - and creatively addressed it. Thousands of students and over one hundred teachers received an education at Eckstein Norton University. These graduates worked to improve the African American community, an act which inherently resisted white supremacy, demonstrating bravery, tenacity, and an immeasurable spirit of hope for the future. ${ }^{35}$ 
${ }^{1}$ John A. Hardin, Fifty Years of Segregation: Black Higher Education in Kentucky, 19041954 (Lexington: University Press of Kentucky, 1997), 2.

${ }^{2}$ Ibid., 3 .

${ }^{3}$ Hilary Green, Educational Reconstruction: African American Schools in the Urban South, 1865-1890, (New York: Fordham University Press, 2016).

${ }^{4}$ Lee L. Brown, “A Short History of Eckstein Norton,” 1911, Eckstein Norton File, Bullitt County Historical Society, Shepherdsville, Kentucky (hereafter BCHS).

${ }^{5}$ Brown, "Short History of Eckstein Norton," Eckstein Norton File, BCHS.

6 "Exercises at Eckstein Norton Institute To-Day," Courier-Journal, November 25, 1909.

${ }^{7}$ Brown, "Short History of Eckstein Norton,” Eckstein Norton File, BCHS.

8 “Eckstein Norton's Will," Courier-Journal, February 9, 1893.

${ }^{9}$ Brown, "Short History of Eckstein Norton," Eckstein Norton File, BCHS.

10 “Eckstein Norton University,” Courier-Journal, March 15, 1896.

${ }^{11}$ Hardin, Fifty Years of Segregation, 25, 26.

${ }^{12}$ Ibid., 29.

${ }^{13}$ Ibid., 12, 13.

${ }^{14}$ Ibid., 21, 22.

${ }^{15}$ Claud W. Perry, "Unit Measure Passes House: Waggoner Draft Prevails By Vote of 63 to 23, Lillard Carter Makes Able Speech Against Bill Aimed at Negro Schools, Goes Through, Extra Employees Get Relief," Courier-Journal, February 27, 1910. 16 "New School Law Upheld," Hopkinsville Kentuckian, June 22, 1909.

17 "Bill Day in the Kentucky House Brings Out Many Measures: Representative Holland, of Shelby, Wants Repeal of Sullivan School Law Which Makes It Possible for the Negro 
to Serve as Trustee," Courier-Journal, January 21, 1910; "Mr. Holland's Indiscretion," Courier-Journal, February 10, 1912.

${ }^{18}$ Hardin, Fifty Years of Segregation, 22.

19 “Dr. A. Eugene Thomson Writes of the Great Advantages the Lincoln Institute Will Give the Negro Youth," Lexington Herald-Leader, August 11, 1912.

20 "Lincoln Institute Not A College," The Courier- Journal, March 29, 1909.

21 "Great School: Planned In the Lincoln Institute of Kentucky," The Courier-Journal, February 8, 1909.

${ }^{22}$ Hardin, Fifty Years of Segregation, 30.

23 “Colored Colleges," Lexington Herald-Leader, April 21, 190.

${ }^{24}$ Ibid.

25 “Lincoln Institute Opens in October," Lexington Herald-Leader, May 12, 1912.

${ }^{26}$ Bureau of Education, "Negro Education: A Story of the Private and Higher Schools for Colored People in the United States," (Washington, D.C.: Bureau of Education, 1916), 274.

27 “Eckstein Norton University,” Eckstein Norton File, BCHS.

28 “Kentucky General Association of Colored Baptists, Diamond Jubilee of the General Association of Colored Baptists in Kentucky: The Story of Seventy-Five Years of the Association and Four Years of Convention Activities, (Louisville: American Baptist, 1943), 41.

29 “C. H. Parrish Sr.,” The Encyclopedia of Louisville, John Kleber, et al., eds.

(Lexington: University Press of Kentucky, 2001), 695.

${ }^{30}$ Hardin, Fifty Years of Segregation, 31, 32. 
${ }^{31}$ C. H. Parrish Jr.," The Encyclopedia of Louisville, 695.

32 James D. Anderson, The Education of Blacks in the South, 1860-1935 (Chapel Hill:

University of North Carolina Press, 1988), 229.

${ }^{33}$ Anderson, The Education of Blacks in the South, 234, 235.

${ }^{34}$ Hardin, Fifty Years of Segregation, 48.

${ }^{35}$ Green, Educational Reconstruction, 9. 


\section{REFERENCES}

\section{PRIMARY SOURCES:}

"An Appeal for Aid: The Faculty and Directors of Eckstein Norton University Ask for Help toward Rebuilding," Courier-Journal, January 27, 1892.

"Atlanta Compromise Speech," New Georgia Encyclopedia;

http://www.georgiaencyclopedia.org (accessed March 11, 2021).

"A Kentucky Tuskegee: Good Work Done at the Eckstein Norton School," The Courier Journal, May 18, 1902.

Beckner, W.M., et al., "Education: Last Day’s Proceedings of the Interstate Convention of Eminent Public Educators, the Proposed Refunding of the Cotton Tax to the States for School Purposes Voted Down, Governmental Aid for the Tuition of the Illiterate Masses Approved by a Large Majority, the State Committee on the Revision of the School Laws Submits Its Report, Which is Adopted, the Educational Question Discussed," Courier-Journal, September 22, 1883.

“Berea College,” Indianapolis Recorder, August 5, 1899.

"Bill Day in the Kentucky House Brings Out Many Measures: Representative Holland, of Shelby, Wants Repeal of Sullivan School Law Which Makes It Possible for the Negro to Serve as Trustee," Courier-Journal, January 21, 1910. 
“Boarding School Ledger,” 1893-1894, Eckstein Norton File, Bullitt County Historical Society, Shepherdsville, Kentucky.

Brown, Lee L. “A Short History of Eckstein Norton,” 1911, Eckstein Norton file, Bullitt County Historical Society, Shepherdsville, Kentucky.

Bureau of Education. Negro Education: A Story of the Private and Higher Schools for Colored People in the United States (Washington, D.C.: Bureau of Education, 1916).

“Colored Colleges,” Lexington Herald-Leader, April 21, 1909.

"Colored Graduates: Commencement Exercises of the State University," CourierJournal, May 20, 1886.

“Commencement of Eckstein Norton Institute,” Courier-Journal, May 25, 1905.

“Dedication of a New Chapel," Courier-Journal, November, 20, 1904.

“Description of Courses,” 1911, Eckstein Norton File, Bullitt County Historical Society, Shepherdsville, Kentucky.

"Dr. A. Eugene Thomson Writes of the Great Advantages the Lincoln Institute Will Give the Negro Youth," Lexington Herald-Leader, August 11, 1912.

“Eckstein Norton," The National Encyclopedia (1891), Eckstein Norton file, Bullitt County Historical Society, Shepherdsville, Kentucky.

"Eckstein Norton," The National Magazine: A Monthly Journal of American History 5 (1892). 
“Eckstein Norton,” Courier-Journal, June 14, 1895.

“Eckstein Norton Day,” Courier-Journal, December 17, 1893.

"Eckstein Norton University." Courier-Journal, Mar 15, 1896.

"Eckstein Norton University Land and Donations," Eckstein Norton File, Bullitt County Historical Society, Shepherdsville, Kentucky.

“Eckstein Norton’s Will,” Courier-Journal, February 9, 1893.

"Education: Help for Colored Schools," Courier-Journal, September 21, 1883

"Educational: The Programme of Exercises for the Inter-State Convention, Which Meeting To-Morrow-Meeting of School Commissioners Night Schools Organized," Courier-Journal, September 18, 1883.

Enrollment of Eckstein Norton University," Eckstein Norton File, Bullitt County Historical Society, Shepherdsville, Kentucky.

"Exercises at Eckstein Norton Institute To-Day," Courier-Journal, November 25, 1909.

"Great School: Planned In the Lincoln Institute of Kentucky," The Courier-Journal, February 8, 1909.

Haves, R.B. "Educational: Arrival of Delegates to the Inter-State Convention, which Assembles in this City this Forenoon, Views of Prominent Educators," CourierJournal, September 19, 1883.

“Increased Facilities for Teaching Science," Courier-Journal, May 12, 1907.

"In Kentucky: Not What He Wanted," Courier-Journal, March 13, 1915. 
"Danville and Vicinity," Kentucky Advocate, January 6, 1888.

"Kentucky General Association of Colored Baptists, Diamond Jubilee of the General Association of Colored Baptists in Kentucky: The Story of Seventy-Five Years of the Association and Four Years of Convention Activities," (Louisville, American Baptist, 1943)

“Lincoln Institute Not A College,” The Courier- Journal, March 29, 1909.

"Lincoln Institute Opens in October," Lexington Herald-Leader, May 12, 1912.

“Mr. Holland's Indiscretion,” Courier-Journal, February 10, 1912.

"Negro Schools Ruining Good Plow Hands: Georgia Judge's Declaration to the Grand Jury—Urges a Change in System of Taxation for Education of Colored Race," Courier-Journal, October 20, 1903.

"New School Law Upheld," Hopkinsville Kentuckian, June 22, 1909.

"New Southern Statesmanship," The North Carolinian (Raleigh) August 13, 1908.

“Obituary,” New York Times, October 31, 1890.

Parrish, C. H. Golden Jubilee of the General Association of Colored Baptists in Kentucky: The Story of 50 Years' Work from 1865-1915 Including Many Photos and Sketches, Compiled from Unpublished Manuscripts and Other Sources (Louisville, Ky.: Mayes Print, 1915).

Perry, Claud W., "Unit Measure Passes House: Waggoner Draft Prevails By Vote of 63 to 23, Lillard Carter Makes Able Speech Against Bill Aimed at Negro Schools, Goes Through, Extra Employees Get Relief," Courier-Journal, February 27, 1910 
"President Frost, of Berea College, Laying Corner Stone of Berea Hall, Lincoln Institute (Negro) in Shelby County," Courier-Journal, October 26, 1911.

“September 17, 2000 (Page 2 of 662)," Courier-Journal, September 17, 2000.

“Taught to Work: Eckstein Norton University's Departure in Colored Education, Girls

Trained to Cook, Sew, and Do Housework and Boys Given Trades the Higher and Elegant Branches of Study Not Neglected but Made Subsidiary, Remarkable Success of an Institution Founded by Mr. Eckstein Norton and Others, Commencement Exercises Yesterday," Courier-Journal, June 18, 1891, p. 6.

“The Beginnings of Eckstein Norton University," Eckstein Norton File, Bullitt County Historical Society, Shepherdsville, Kentucky.

“The Efficacy of Work," Courier-Journal, June 15, 1890.

“The Governor of Kentucky,” Indianapolis Recorder, February 6, 1904.

"The Last Rites: Final Services Over the Remains of the Late Rev. Dr. W. J. Simmons the Funeral One of the Largest Ever Taking Place in the City," Courier-Journal, November 4, 1890.

"The Lincoln Institute." Courier-Journal, February 91909.

"The Negroes of Kentucky." Courier-Journal, February 19, 1870.

“The Rev. Simmons Dying”. Courier-Journal, Oct 26, 1890.

"To Be Buried Monday: Final Services Over Remains of the Late Rev. Dr. W. J. Simmons," Courier-Journal, November 1, 1890. 
Washington, Booker T. Up from Slavery (New York: Doubleday, 1901).

Washington, Booker T. "The Religious Life of the Negro." The North American Review 181, no. 584 (1905): 20-23.

\section{SECONDARY SOURCES:}

Anderson, James D. The Education of Blacks in the South, 1860-1935 (Chapel Hill University of North Carolina Press, 1988).

Ayers, Edward. The Promise of the New South: Life After Reconstruction (New York: Oxford University Press, 1992).

Bauerlein, M. (2004). Washington, Du Bois, and the Black Future. The Wilson Quarterly (1976-), 28(4), 74-86.

Blight, David W. Race and Reunion: The Civil War in American Memory. Cambridge, MA: Harvard University Press, 2001.

"C. H. Parrish Jr.," The Encyclopedia of Louisville, John Kleber, et al., eds. (Lexington: University Press of Kentucky, 2001).

“C. H. Parrish Sr.," The Encyclopedia of Louisville, John Kleber, et al., eds. (Lexington: University Press of Kentucky, 2001).

Equal Justice Initiative, Lynching in America: Confronting the Legacy of Racial Terror, $3^{\text {rd }}$ ed. (Montgomery, AL: Equal Justice Initiative, 2017).

Gilmore, Glenda. Gender and Jim Crow: Women and the Politics of White Supremacy in North Carolina, 1896-1920 (Chapel Hill: The University of North Carolina Press, 1996), 
Goodwyn, Lawrence. The Populist Moment: A Short History of the Agrarian Revolt in America," (New York: Oxford University Press, 1978).

Green, Hilary. Educational Reconstruction: African American Schools in the Urban South, 1865-1890. (New York: Fordham University Press, 2016).

Harlan, Louis R. Booker T. Washington: The Making of a Black leader, 1856-1901, (New York: Oxford University Press, 1972).

Hershberg, Theodore. "Free Blacks in Antebellum Philadelphia: A Study of Ex-Slaves, Freeborn, and Socioeconomic Decline." Journal of Social History 5, no. 2 (1972): 183-209.

Josephson, Mathew. The Robber Barons: Great American Capitalists; 1860-1901 (New York Harcourt: Brace and Company, 1934).

Klein, Maury. History of the Louisville and Nashville Railroad, (New York: The Macmillan Company, 1972).

"Louisville, Kentucky. Seasonal Average Temperatures, Total Precipitation, and Total Snowfall." The National Weather Service. https://www.weather.gov/media//mk/climate/clisdf/seasonal_av_temp_total_preci p_total_snow.pdf (accessed Feb. 23, 2021).

Nelson, Paul David. "Experiment in Interracial Education at Berea College, 1858-1908." The Journal of Negro History 59, no. 1 (1974): 13-27.

Noyes, Alexander D. "The Banks and the Panic of 1893." Political Science Quarterly 9, no. 1 (1894): 12-30. 
Ryant, Carl. “'Where the Railroad Was, the River Is': Oral History from L\&N Workers." The Register of the Kentucky Historical Society 82, no. 1 (1984): 6071.

"Simmons, William J., "The Encyclopedia of Louisville, John Kleber, et al., eds. (Lexington: University Press of Kentucky, 2001).

Simpson, John A. "The Cult of the "Lost Cause"." Tennessee Historical Quarterly 34, no. 4 (1975): 350-361.

Tipton, C. Robert, "The Fisk Jubilee Singers." Tennessee Historical Quarterly 29, no. 1 (1970): 42-48.

Wright, George. Racial Violence in Kentucky, 1865-1940: Lynchings, Mob Rule, and “Legal Lynching”s (Baton Rouge: Louisiana State University Press, 1990).

Watson, Harry. "Front Porch." Southern Cultures 24, no. 2 (2018): 1-3. 


\section{CURRICULUM VITAE}

NAME:

EDUCATION

AND TRAINING:
Samuel Thomas Dunn

\section{B.A., Anthropology and History \\ University of Louisville}

2015-2019

\author{
M.A., History \\ University of Louisville
}

2019-Present 